\section{Arkeotanatoloji ve Anadolu Arkeolojisi'nde uygulanması (Tekli birincil gömütler)}

\author{
Yasemin YIImaz ${ }^{1 *} \odot$ \\ 'Dr. Öğr. Üyesi | Düzce Üniversitesi, Fen Edebiyat Fakültesi, Arkeoloji Bölümü, Düzce - Türkiye
}

* Sorumlu Yazar / Corresponding Author: Yasemin Yılmaz Düzce Üniversitesi, Fen Edebiyat Fakültesi Arkeoloji Bölümü Konuralp Yerleşkesi, 81620 Merkez Düzce / Türkiye

E-posta: yaseminyilmaz@duzce.edu.tr

Alındı/Received: 21 Nisan / April 2021 Düzeltildi/Revised: 21 Haziran / June 2021 Kabul/Accepted: 25 Haziran / June 2021 Yayımlandı/Published: 28 Haziran / June 2021

\section{Öz}

Gömüt, ölen birey için, yaşayanlar tarafından oluşturulan, mimarisi, dolgusu, ölü nesnesi, bulunduğu alan ve zamanın bileşimidir. Arkeotanatoloji, arkeolojik kazılarda açı̆̆a çıkarılan gömütlerden, iskeletlerden/insan kemiklerinden, farklı analitik yöntemler kullanılarak üretilen verilerle, geçmişte yaşamış toplumların ölü gömme uygulamalarının belirlenmesidir. Arkeolojik bağlamların etkileşimli olarak ele alınması, cesedin iskeletleşme sürecinin tafonomik analizi, iskelet sistemini oluşturan kemiklerin eklemlenmelerinin dağılma kronolojisi gibi analitik araçlarla, arkeotanatoloji, farklı nitelikteki gömütlere özgü sistematik yaklaşımlar önermektedir. Yöntemin kuruluşuna 1980’lerde Fransız bilim insanları Henri Duday ve Claude Masse öncülük etmiştir. Günümüzde Fransa'da gömüt analizlerinin temelini oluşturmakta, Avrupa ülkelerinde de kullanımı yaygınlaşmaktadır. Yöntem, Anadolu Arkeolojisi’nde ilk olarak Aşıklı Höyük'te kısmî olarak arazide ve Çayönü Kafataslı Bina’da açığa çıkarılan insan kemiği kalıntılarının laboratuvar analizlerinde kullanılmıştır. Arkeotanatoloji, makalenin yazarı tarafından son yıllarda Ilısu Baraj Projesi kapsamında kazılan Çemialo Sırtı'nda ve İstanbul'daki Yenikap1, Pendik, Sirkeci, Sulukule, Beşiktaş ve Haydarpaşa kurtarma kazılarında bulunan gömütlerin analizinde kullanılmaktadır. Makale, birincil tekli gömütlerin kazı ve analitik araçlarına odaklanmaktadır. Farklı tipteki gömütlerden seçilen örnekler aynı zamanda arkeotanatolojik yöntemin uygulanmasında referans niteliğindedir.

Anahtar sözcükler: Arkeotanatoloji, tafonomi, birincil gömüt, Anadolu Arkeolojisi

\section{Giriş}

Arkeoloji bilimi, kalıntılanı geçmişte yaşamış toplumu temsil eden "simgeler/şeyler" olarak kabul ederek, nesnelerden veya nesne topluluklarından, öznelerin biçimlendirdiği eski toplumları yeniden oluşturma hedefiyle incelemektedir. Arkeolojik kalintilar ve buluntu toplulukları, topluma dair farklı bilgileri içeren öbekler olduğundan arkeolojik bilginin üretimi de düşünce ve yöntem çeşitliliğini zorunlu kulan çok katmanlı bir faaliyettir. Birbirinin kalitesini/ niteliğini doğrudan etkileyen kazı, analiz, sentez ve

\section{Archaeotanatology and its application in Anatolian} Archaeology (Individual primary burials)

\section{Abstract}

Burial, for the dead individual, is created by the living. It is a compound of its architecture, fill, dead object, space, and time. Archaeotanatology is the determination of burial practices of the past societies, using different analytical methods and data from archaeological burials, skeletons/buman bones. With analytical tools such as the interactive handling of archaeological contexts, the taphonomic analysis of the skeletonization process of the body and the chronology of the articulation of the bones forming the skeletal system, archaeotanatology suggests that these buried objects should be examined using a special method. French scientists Henri Duday and Claude Masse pioneered the establishment of the method in the 1980s. Today, it forms the basis of burial analysis in France, and its use is becoming widespread in European countries. In Anatolian Archeology, the method was first partially used in the field at Asıkle and in the laboratory analysis of buman remains unearthed at Cayönü Skull Building excavation. In recent years, the author of the article applied archaeotanatological methods in the analysis of burials unearthed from the Cemialo Ridge excavations within the scope of the Ilisu Dam Project, and Yenikapi, Pendik, Sirkeci, Sulukule, Beşiktas and Haydarpaşa excavations in Istanbul. This paper focuses on the excavation and analytical tools of primary individual burials. Samples selected from different types of burials can also be used as a reference in the application of the method.

Key words: Archaetanatology, taphonomy, primary burial, Anatolian Archaeology

yorum süreçleri bütünlüğü parçalanmış kalıntının içerdiği bilgiyi açığa çıkarmanın birbirini sarmalayan yollarıdır. Kazı çalışmasında buluntunun "doğasını" ve arkeolojik bağlamını tahrip etmeyecek tekniklerin tercih edilmesi, analiz aşamasında, kalınt//buluntu topluluklarının içerdiği bilgiyi ortaya çıkaracak farklı yöntemlerin ilişkisel olarak kullanılması, sentezde ise bütün süreçlerin aşamalı olarak değil, bir sarmal biçiminde birbirini etkileyen/etkilenen döngüsünde diyalektik bir yaklaşımla değerlendirilmesi zorunludur. Gömütler, birçok ritüelin belirli inanç formlarının 
temsilcileri olarak değerlendirilmekte, toplumun "soyut" birlikteliklerinin kurulum araçlarından biri olarak işlev görmekte ve eski toplumların ölüm karşısında aldığ1 tutumların bilgisini içermektedir (Leroi-Gourhan, 1964, s. 53-65; Thomas, 1978, s. 10-12; Barnard, 2012, s. 71). Tanatoloji, ölümü biyolojik ve sosyal olguların bileşeni olarak ele alarak bu karmaşık yapının anlaşılabilmesi için katkı sağlamaktadır (Duday, 2011, s. 3).

Eski toplumların ölü gömme uygulamalarının seyri, toplumlar arasında önemli farklar olmakla birlikte, çok genel bir çerçeveyle üç aşamada sınıflanabilir. İlk aşama, cesedin gömülmeye hazırlanmasıdır. Bedenin hasıra sarılması, ahşap bir kutunun içine konulması, giydirilmesi, ölü makyaj1 vb. uygulamalar bu aşamaya örnek verilebilir. Gömülme süreci ikinci aşamayı oluşturmaktadır. Cesedin gömülmesi, mezar mimarisi ve bileșenleri, bedenin yatırılış biçimi, ölü nesneleri, cesedin etrafinın doldurulması veya boş bırakılması, ölünün yakilmasindan (kremasyon) sonra geriye kalan kemiklerin gömülmesi vb. birçok uygulama ile temsil edilmektedir. Üçüncü aşama, gömülme işlemi tamamlandıktan sonra ki olgulara odaklanmaktadır. Gömütün yeniden açılarak, başka bir cesedin gömülmesi için yer açılması, cesedin/ iskeletin/bazı kemiklerin ilk konulduğu yerden alınarak farklı bir yere taşınması, gömütün günümüze geldiği süreçte farklı toplumların müdahalesine maruz kalması ve mezarların soyulması, tahrip edilmesi gibi olgulardan oluşur (Crubezy vd., 1992, s. 25; Crubezy, 2000, s. 22-23; Duday, 2011, s. 7-12; Sprague, 2005, s. 21-22). Ölülerin gömülmesindeki farklı uygulamalara denk düşen bu üç aşamaya ait, gömütlerde tespit edilecek kalıntılar/izlerle sözü edilen aşamaları tanımlamak ve eski toplumların ölü gömme uygulamalarını yeniden oluşturmak mümkündür. $\mathrm{Bu}$ verilerin tespiti için ise; gömütlerdeki arkeolojik bağlamlarında, kazı-analiz-sentez yoluyla açığa çıkarılması, değerlendirilmesi ve yorumlanmas1 gerekmektedir (Boulestin ve Duday, 2005; Duday, 2005; Duday, 2011).

\section{Gereç ve yöntem}

Arkeolojik çalışmalarda yöntem, elde edilecek sonuçlar üzerinde doğrudan etkilidir. $\mathrm{Bu}$ nedenle arkeolojik kalıntıların doğasına uygun sistematik analizler, eski toplumların anlaşılmasının önemli araçlarıdır. Makalede anlatılan yöntem, gömütlerin arkeolojik bağlamı, tafonomik süreci, biyolojik analizlerinin ilişkisel olarak değerlendirilmesine odaklanmaktadır. Bu yolla, gömütlere etki eden doğal süreçler ve toplumun iradî müdahalelerini birbirinden ayrıştırarak, eski toplumların ölü gömme geleneklerini ortaya koymaktadır. Makalede, arkeotanatolojik yöntemin Anadolu'nun çeşitli bölgelerinde açığa çıkarılmış, farklı arkeolojik dönemlere tarihlenen gömütlere uygulanarak, elde edilen sonuçların sunulması ve yöntemin değerlendirilmesi amaçlanmaktadır.

Arkeotanatoloji Anadolu Arkeolojisi'nde ilk olarak Aşıklı Höyük'te kısmî olarak arazide, gömütlerin kazılması ve belgelenmesinde kullanılmıştır. Ayrıca kazıda çekilen fotoğraflar, çizimler, notlar yardımıyla bu yaklaşım yordamıla 1989-2000 yılları arasında açığa çıkarılmış gömütler değerlendirilmiştir (Yılmaz, 2002). Çayönü Kafataslı Bina'daki iskelet kalıntılarının laboratuvar çalışmaları bu yöntemle yürütülmüştür (Le Mort vd., 2000; Y1lmaz, 2010; Y1lmaz, 2019). Yöntem, Ilısu Baraj Projesi kapsamında, Çemialo Sırtı kazısında ve özellikle İstanbul'da bayındırlık projeleri (20082020) kapsaminda kazilan Yenikap1 (Y1lmaz, 2011), Pendik, Sirkeci (Yllmaz, 2019), Vezneciler ve Sulukule projelerinde tarafimdan kullanılmıştır. Makale, teorik ve uygulama olmak üzere iki bölümden oluşmaktadır. Arkeotanatolojik yöntemin kuruluşu, analitik araçları, kazı ve belgeleme önerileri, tekli birincil gömütlerdeki analiz yöntemi, gömüt yapısı ve bileşenleri teorik kısmı oluşturmaktadır. Anadolu Arkeolojisi'ndeki arkeotanatolojik çalışmalardan sunulan örneklerle ise yöntemin uygulanmasından elde edilen sonuçlar değerlendirilmektedir.

\section{Arkeotanatolojik yöntemin tarihçesi}

Arkeotanatolojinin ayırt edici özelliği, gömütlerin arkeolojik bağlamı ve tafonomik süreciyle birlikte incelenmesine odaklanmasıdır. Bu iki olgu ile gömütlerin birlikte değerlendirildiği en eski örneklerinden birisi İsveçli Arkeolog Frederic Troyon tarafindan belgelenen, 1838'de Cheseaux'ya yakın Bel-Air'de Orta Çağ'a tarihlenen mezarlar; diğeri ise 1901'de Neolitik Dönem'e tarihlenen Chamblandes a Pully'deki mezarlikta Albert Naef'in yaptığı çalışmadır (Fabre vd., 1997). AndreLeroi-Gourhan ve ekibi tarafindan Marne'deki MesnilSur-Orge'de Mournardaki II. Hypoje kazısı ve İsviçre'de Sion'daki Petit Chasseur Nekropolü'ndeki kazılar arkeolojik bağlam analizinin çoklu gömüt ortamlarına uygulandığ1 erken örneklerdir. Anatomik bağlantıları devam eden iskeletler, kafataslar1-alt çeneler ve "izole kemikler" gibi farklı nitelikteki insan kalıntılarının detaylı olarak arazide belgelenmesi, aynıbireye ait kemiklerin kazı ortamında ayırt edilerek, çizimler üzerine işaretlenmesi sonucunda, ölülerin gömülme süreci ve gömüt ortamının yeniden düzenlenme biçimleri belirlenmiştir (LeroiGourhan vd., 1962; Gallay ve Chaix, 1984). Gömüt çalısmalarında sistematik olarak yöntemler üretilmesi, standartlarının oluşturulması terminolojik çerçevesinin kurulması ve uygulamada süreklilik kazanması açısından Fransa'nin Touluse kentinde, H. Duday ve C. Masset tarafindan 1982'de düzenlenen Anthropologie Physique et Archeologie sempozyumu ve devamındaki yayın (Duday ve Masset, 1987) önemlidir. Sempozyumda, geleneksel gömüt çalışmalarnna yöneltilen eleştiri iki yönlüdür: İlki, 
gömüt kazılarının, insan osteolojisi eğitimi olmayan arkeologlar tarafindan yapilarak, insan iskeletleri dışında, özellikle de mezarlarda bulunan nesnelerden elde edilen verilerin "ölü gömme gelenekleri” olarak değerlendirilmesi; ikincisi ise gömütlerden çıkarılan insan iskeletlerinin biyolojik analizlerinin, fizikî/ biyolojik antropologlar tarafindan yapılarak, gömütlerin arkeolojik bağlamı ile ilişkilendirilmeden demografik verilerin yayımlanmasıdır. Arkeotanatolojinin eleştirisi veri üretme sürecinin ikili yapısının, onların gömütlerin anlaşılmasını ve eski toplumların ölü gömme uygulamalarının belirlenmesini zorlaştırdığı yönündedir (Crubezy, 2000, s. 11; Duday ve Guillon, 2006). Bu soruna çözüm olarak, gömütlerin arkeolojik bağlamları, dolgusu, mezar mimarisi ve cesedin tafonomik süreciyle birlikte ele alınması gerektiğine dikkat çekilmektedir. Gömütlerin arazi çalışması ve laboratuvar analizlerinin ilişkisel olarak, aynı ekipler tarafindan yürütülerek ölü gömme uygulamalarının bütünsel olarak değerlendirilmesi gerektiği belirtilmektedir. Bu yeni disiplin, arkeoloji ve antropolojnin yöntemleriyle yoğrulmuş, bir ara yüz olarak da düşünülmüş ve başlangıçta Mezar Arkeolojisi ve Alan Antropolojisi olarak ikili adla sunulmuștur (Duday, 1978, 1981, 1990, 1995, 1997, 2005; Duday vd., 1990). Geliştirildikten sonra kendine geniş bir uygulama alanı bulan ve artık gelenekselleşmeye başlayan bu yöntem, 2005 yllında H. Duday ve B. Boulestin tarafindan "Arkeotanatoloji" olarak adlandırılmıştır (Boulestin ve Duday, 2005, s. 13). Yöntem, ölüm olgusunu biyolojik ve sosyolojik boyutlarıyla ele almaktadır. Arkeotanatoloji, morfolojik ve arkeometrik analizler, kemikler üzerinde iz bırakan hastalıklar, antik DNA analizleri ve tarihsel süreçteki değişimlerinin belirlenmesi gibi etkileşimli çalışmalar yoluyla geçmişte yaşamış toplumların sosyal yapılarının anlaşılması, demografilerinin ve beslenme sistemlerinin belirlenmesine çalışmaktadır (Tillier, 2009).

\section{Yöntemin analitik araçları: Tafonomi}

Tafonomi, Yunanca'daki taphos (gömme, gömüt, kabir) ve nomos (âdet, gelenek, alışkanlık) sözcüklerinden türetilmiştir (Duday, 2005, s. 164). Tafonomi, Efremov (1940) tarafindan "gömme/gömülme bilimi" olarak tanımlamış, ölmüş hayvan kalıntılarının, biyosferin farklı aşamalarından geçerek fosilleşmesi ve litosferin bir parçası haline dönüşmesi olgusuna dikkat çekmiştir. Tafonomi biliminin temel problematiği hayvanların imhası, ölü hayvanların (biyolojik kalıntıların) gömülmesi ve devamındaki değişim süreçlerinin (biyosferdenlitosfere geçişlerinin) sinıflandırılarak detaylarıyla incelenmesi olarak değerlendirilmiştir (Efremov, 1940). 1980'li y1llardan itibaren, özellikle İngiliz ekolünde Arkeozooloji alanında tafonomik yöntem yaygın olarak kullanılarak, terminolojik çerçevesi tanımlanmış ve çok sayıda ampirik çalışma yayımlanmıştır (örn. Lyman, 1987; Andrews, 1997). Ayn1 y1llarda Fransız ekolü, Arkeozoolojik çalışmaların yanı sıra, tafonomik yaklaşımı (Alan Antropoljisi/Mezar Arkeolojisi) ölü gömme uygulamalarının değerlendirilmesinde kullanmaya başlamıştır (Duday; 1978). Duday'ın (2006, 2011) çalısmalarının İngilizceye çevrilmesiyle, tafonominin ölü gömme uygulamalarında kullanımı yaygınlaşmışır (Knusel ve Robb, 2016, s. 2). Bireyin ölümüyle başlayan süreç, gömülme öncesi, gömülme aşaması ve gömülme sonrasında cesedin iskeletleşmesinde etkili olan doğal ve yapay etkileri ayrıştırarak ölü gömme uygulamalarını belirlemek için tafonomik analizler kullanılmaktadır (Mickleburgha ve Wescott, 2016). Arkeolojik kazllarda açığa çıkarılan iskelet kalıntılarının, cesedin gömüte ilk konulma biçiminden, iskeletleşme sürecindeki değişimler nedeniyle bazı durumlarda farklılaşmalar oluşmaktadır. Özellikle kazılar sırasında, iskelet kalıntılarının in situ halleriylebelgelenerek, anatomik ve tafonomik analizlerle, cesedin gömüte eski toplum tarafından yatırılış biçimi yeniden oluşturulabilmektedir (Knusel, 2014, s. 27). Bu bağlamda Arkeotanatoloji, gömüt uygulamaları üzerine çalışma yöntemi ile tafonomi teriminin etimolojisine uygun bir içerik kazandırmaktadır (Duday, 2011, s. 13).

Tafonomik veriler, gömütlerin/iskeletlerin/insan kemiği kalıntılarının bulunduğu arazide ve daha sonra laboratuvarda kemikler üzerinde yapılan çalışmalardan elde edilmektedir (Knüsel ve Robb, 2016). Özellikle laboratuvar ortaminda kemik yüzeylerin dikkatli biçimde taranması, cesedin iskeletleşme sürecine insanların aktif müdahalesi olarak yorumlanan kesik izlerinin belirlenmesi açısından önemlidir (Le Mort, 1990). Bununla birlikte, gömütlerin ve cesetlerin süreç içerisinde geçirdiği farklı etkilerden kaynaklı değişimlerin tespitinde, özellikle, kalıntıların bağlamıyla birlikte, kazılar sırasında yapılan tafonomik analizler belirleyicidir (Duday ve Guillon, 2006). Insan bedeni, normal koşullarda ${ }^{1}$, ölümden sonra katılaşma, yumuşak dokuların çürümesi ve eklemlenmelerin dağılması gibi bir dizi değişim ${ }^{2}$ geçirerek iskeletleşmektedir (Alemdar ve Cavlak, 2019, s. 605-611). İlk aşama olan katılaşma, ölümden sonraki 3-5 saat içerisinde başlamaktadır. Bu aşamada öncelikle çenede bir kasılma ve el parmaklarında bükülmeler oluşur. Devamında kasılmalar bütün vücuda yayllır. Katılaşma, ortalama koşullarda 38-48 saat sonra çürümenin başlamasıyla sonlanmaktadır (Crubezy,

\footnotetext{
${ }^{1}$ Mumyalama, cesedin yakılması, insanlar tarafindan bilinçli parçalanması vb. olgular

${ }^{2}$ Ölümden sonrageçirilen değişiklikler:Temelvücutfonksiyonlarının kayb1, kasların gevşemesi, sıvı kaybı, kanın pıhtılaşması ve hemolizi, ölü soğuması (algor mortis), ölü lekeleri (livor mortis), ölü sertliği (rigor mortis), yumuşak dokuların çürümesi (Alemdar ve Cavlak, 2019, s. 605-608).
} 
2000, s. 28; Koç ve Can, 2009, s. 18; Rogers, 2010, s. 29). Gövdenin gevşemeye başlamasının ilk belirtisi olarak, alt çene aşağ1 düşmekte ve çürüme evresi başlamaktadır. Çürümeye, gazların vücut içerisinde birikmesi eşlik eder. Gaz birikimi, karın ve göğüs çevresinde şişmeye neden olmakta, belirli bir sürenin sonunda gaz basıncının etkisiyle bu bölgedeki şişme bir patlamayla sonlanmaktadır (Crubezy, 2000, s. 28; Koç ve Can, 2009, s. 19; Alemdar ve Cavlak, 2019, s. 610). Ĕger ceset gömülürken, eller karnın üzerine konulmuş ve cesedin etrafı gömüldükten sonra toprakla doldurularak bir karşıt basınç oluşmamış ise özellikle dayanıksız eklemlenme bölgeleri olan el parmak kemiklerinin, oluşan patlamanın etkisiyle yer değiştirebileceğine dikkat çekilmektedir (Fabre vd., 1997; Crubezy, 2000, s. 28). Ilıman iklim koşullarında, gömülen cesetlerde, ortamın özelliklerine de bağlı olarak, iskeletleşmenin tamamlanmasının, kesin olmamakla birlikte, en erken 1-2 yılda, ortalama $3-5^{3}$ yılda, bazense gömüldüğü ortamın niteliği nedeniyle 10 yilda tamamlandığına dair veriler vardır (Koç ve Can, 2009, s. 20; Arslan ve Koç, 2016, s. 18). İskeletleşme süreci, ölen bedenin yapısına, bedenin konduğu ortamın iklimine, toprak yapısına, gömüldüğü alanın biçimine, cesedin çevresini sarmalayan dolguya, açık havada olup olmadığı gibi farklı birçok etkene göre çeşitlenmektedir. Ayrıca, cesede gömülmeden önce yapilan uygulamalar da etkilidir (Duday ve Guillon, 2006; Peressinotto, 2007, s. 7; Mickleburgha ve Wescott, 2016; Houck ve Siegel, 2016, s. 175). Ayrica cesedin çürüme hızı yürüme düzleminden ne kadar aşağıya gömüldüğüyle de ilgilidir. Ceset yürüme düzleminden 30-60 cm aşağıya gömüldüğünde yumuşak dokuların yok olma hızının daha yüksek olduğu, 1-2 m daha derine gömüldüğünde ise çürüme hızının yavaşladığ1 belirtilmektedir (Peressinotto, 2007, s. 7, 32).

\section{Insan iskelet sisteminde anatomik duruş ve eklemlenmelerinin sonlanma kronolojisi}

Arkeotanatolojik yöntemde, anatomik duruş analizi ve eklemlenmelerin sonlanma kronolojisi, gömüte etki eden farklı olguları belirlemek için kullanılmaktadır. Bunlardan ilki, cesetlerin iskeletleşme sürecinde ve gömüt ortamının değişiminde etkili olan doğal olgular (erozyon, fiziksel-kimyasal bozulmalar,

\footnotetext{
${ }^{3}$ Resmî Gazete'de yayımlanan 19 Ocak 2010 tarih ve 27467 sayılı Mezarlık Yerlerinin İnşası ile Cenaze Nakil ve Defin İşlemleri Hakkında Yönetmelik'in 39. maddesinin 4. fikrasında "Bir mezar yerine mükerrer defnin ne kadar zaman sonra yapılabileceği, mezarlık yer seçimi komisyonu tarafindan, toprağın cenazeyi tam olarak tahrip edebilme kabiliyetine bakılarak mezarlık yerinin tespiti esnasında 5 seneden az olmamak üzere belirlenir" ifadesi yer almaktadır (bkz. https://www.mevzuat.gov.tr). Bu yasa maddesi de Türkiye'de gömülen cesetlerin iskeletleşme süreçlerinin ortalama 5 yıl olduğuna dair dolaylı bil veri olarak değerlendirilebilir.
}

mikroorganizma etkinlikleri ve toprağ 1 kazan, kemirgen hayvanlar) belirlenerek gömütün geçirdiği süreci yeniden oluşturulmasinda (Crubezy vd. 1992, s. 22; Duday, 2005, s. 164). İkincisi, gömütlere sonradan yapilan müdahalelerin belirlenmesi, birincil ve ikincil gömütlerin birbirinden ayırt edilmesinde. Üçüncüsü cesedin gömüldüğü ve iskeletleșme sürecini geçirdiği ortamın (boș veya dolu) yeniden oluşturulmasında. Dördüncüsü cesedin kalıntı birakmayan bir nesne ile (hasır, tabut vb.) gömülme durumunun belirlenmesinde (Mickleburgha ve Wescott, 2018, s. 159). Anatomik duruş, karşımızda ayakta, yüzü bize dönük, baş ve gövdesi dik, kolları yanlardan aşağıya sarkık, avuç içi (el ayas1) öne bakan, topukları ve ayak başparmakları bitişik duruş biçimidir (Çimen, 1994, s. 10). Gömütlerde açığa çıkarılan insan iskeletlerinde ki anatomik duruş ise, iskelet sistemini oluşturan kemiklerin, orijinal yerlerinde kalması, yer değiștirmemiș ve iskelet sistemini olușturan kemiklerin eksik olmamasıdır. İnsan iskelet sistemindeki eklemlenmelerin sonlanma süreci kronolojiktir (Duday, 1995, s. 36; Duday, 2005, s. 166; Knüsel, 2014, s. 30). İskelet sistemindeki eklemlenmelerin sonlanma süresi, arkeolojik alanlarda kazılan gömütlerdeki iskeletlerin incelenmesiyle oluşturulan verileri temel almaktadır. Ayrıca, yaşayan insanlarda yumuşak dokuların hacmi ve iskelet sistemindeki eklemlenmelerin biyomekanik isslevi, adli tıp çalışmalarından elde edilen bilgiler ve hayvanlar üzerinde yapılan deneysel çalıșmaların sonuçları da eklemlenmelerin sonlanma kronolojilerinin belirlenmesinde kullanılmaktadır (Duday ve Guillon, 2006; Peressinotto, 2007; Knüsel, 2014; Mickleburgha ve Wescott, 2018).

Insan iskelet sisteminde, en erken sonlananlar dayanıksız, en geç sonlananlar ise dayanıkl1 ${ }^{4}$ eklemlenme olarak adlandırılmakta (Duday, 2011, s. 26) ve iki uç sınırı işaret etmektedir. Bununla birlikte, bütün eklemlenmeler, dayanıksız ve dayanıklı grubuna dâhil edilmemekte, bu iki sınırın içerisinde, eklemlenmeler farklı zamanlarda kronolojik olarak sonlanmaktadir (Peressinotto, 2007, s. 32). İskeletleşmeden sonra, yumuşak dokuların yok olmas1 ve eklemlenmelerin sonlanmasiyla her bir kemik, farklı etkilerle yer değiştirebilecek duruma gelmektedir. Dağılma evresinin süresi öncelikle kemik öğeleri birbirine bağlayan eklemlenmelerin durumuna, çevresel koşullara ve ölü gömme uygulamalarına göre farklılaşmaktadır. Ceset gömülmeden açığa birakılmış ise eklemlenmeler birkaç haftada sonlanabilmektedir. Kuru bir ortamda gömülmüş ise birkaç bin yıl dağılmadan kalmaktadır (Crubezy, 2000, s. 28; Mickleburgha ve Wescott, 2018). Ölünün yakıldığ 1 kremasyon uygulamalarında eklemlenmelerin sonlanması saatlerle ifade edilmektedir

\footnotetext{
${ }^{4}$ Connexion labile dayanıksız eklemlenmeler, Connexion persistante ise dayanıklı eklemlenme olarak Türkçeleştirilebilir.
} 
(Grevin, 2004). Ayrıca eğer ceset açık alanda ve yırtıc1 hayvanların etkisine açı ise eklemlenmelerin sonlanması hızlıdır. Yapay veya doğal mumyalarda ise eklemlenmeler çok uzun süre korunmaktadır. Konumuz bağlamında eklemlenmelerin sonlanma kronolojisi, llıman koşullarda gömülmüş, dış etkilere kapalı ortamlarda bulunan cesetlerin iskeletleșmesi ve eklemlenmelerin sonlanma kronolojisini temel alınmaktadır (Duday, 2005, s. 166).

Dayanıksız eklemlenmeler, özellikle küçük boyutlu kemiklerin bulunduğu bölgelerde, yumuşak dokuların daha ince olduğu alanlardadır. Bunlar insan iskelet sistemindeki hyoid, temporal-mandibula, el bilek, tarak kemikleri ve parmak kemikleri, ayak parmak kemikleri, boyun omurlar1, skapula-humerus eklemlenmesi, skapula ve kaburga, kaburga ve sternum ile patella'dır (Duday, 2005, s. 167; Duday, 2011, s. 27; Knüsel, 2014, s. 32). Dayanıksız eklemlenmelerin, ceset gömüldükten sonra, birkaç hafta içinde sonlandığı bildirilmektedir (Duday, 2005, s. 167; Knüsel, 2014, s. 237). Bu nedenle, ceset gömüldükten sonra, gömüte/iskelete müdahale edildiğinde, bu durumun ancak dayanıksız eklemlenme bölgelerinde iz birakabileceği belirtilmekte ve arkeolojik alanlarda açı̆̆a çıkarılan iskeletlerin "birincil bağlamda $\mathrm{m} 1$ yoksa ikincil bağlamda mı olduğu; boş bir alanda mı yoksa dolu bir alanda $\mathrm{m}$ iskeletleştiği” gibi sorulara, dayanıksız eklemlenme bölgelerindeki kemiklerin durumlarının değerlendirilmesiyle yanıt üretilmesi gerektiğine dikkat çekilmektedir (Duday, 2011; Duday vd., 2014)

Dayanıklı eklemlenmeler ile birbirine bağlanan kemiklerin, ana bağ dokular, tendonlar ve kaslar nedeniyle eklemlenmelerin sonlanmasinin daha uzun süreye yayıldığı belirtilmektedir (Knusel, 2014, s. 32). Dayanıklı eklemlenmeler; bel omurları, beşinci bel omuru-sakrum, sakrum-pelvis, femur-tibia, tibiafibula-talus eklemlenmesi ve ayak bilek-ayak tarak eklemlenmeleri bu grupta değerlendirilmektedir. Pelvisfemur eklemlenmesinin ise biraz daha hizlı sonlandığ belirtilmektedir (Duday, 2005; 2011). Gömüte yapılan müdahalelerin dayanıklı eklemlenmelerle birbirine bağlanan kemikler üzerinde iz birakmasının daha uzun süre alması nedeniyle, gömütlerin analizinde, iskeletler üzerindeki yer değişikliği belirlemelerinde dayanıksız eklemlenme bölgelerinin özellikle incelenmesi gerekmektedir (Duday, 1990; Duday ve Sellier, 1990; Duday vd., 1990; Duday, 1995)

\section{Gömütlerin kazılması, belgelenmesi ve iskeletlerin kaldırılması}

Arkeotanatolojinin ayırt edici özelliği, arkeolojik bağlam ile iskeletin biyolojik analiz süreçlerini ilişkisel olarak değerlendirmekte 1srarc1 olmasıdır. Bu nedenle kazı, gömütün içi (iskelet, kemik parçası, ölü nesnesi, mezar mimarisi, dolgu vb.) ve gömütle bağlantılı diğer öğelerin (örneğin içinde bulunduğu mekân, altında olduğu taban, stratigrafi, gömütü çevreleyen ve ilişkili olduğu, olma potansiyeli olan her şey) eşit detayda belgelenerek ilişkilendirilebilecek biçimde organize edilmelidir (Crubezy, 2000, s. 21-22).

Ölügömme uygulamalarından söz etmeninilk koşulu bireyin bilinçli olarak gömülmüş olduğuna dair verilerin net olmasıdır (Henry-Gambier, 2008, s. 167). Gömüt için, en azından bireyi/bireyleri temsil eden insan kemiği kalıntıları (birincil veya ikincil) ve bilinçli gömmenin göstergesi olarak "gömüt yapısı" tanımlanabilmelidir (Leclerc, 1990, s. 14; Henry-Gambier, 2008, s. 167; Bocquentin vd., 2010, s. 160). Bu temel gerekliliklerin yanı sıra, gömütleri tanımlamak için ek ölçütler zamana ve kültürlere göre değişerek çeşitlenmektedir. İskeletin anatomik pozisyonu, yatırllış biçimi, yönü, ölü nesnesi (Ölü ile birlikte gömüldügü belirlenen bütün nesneleri içermektedir), ölünün gömülmeden önce bir hazırlıktan geçip-geçmediği, iskeletle birlikte okr vb. boyaların olup olmaması gibi ek göstergeler de söz konusudur (HenryGambier; 2008, s. 167; Bocquentin vd., 2010, s. 160). Ölü gömmede yaygın olarak karşılaşılan uygulama; ölünün öncelikle toprağa açılan çukurların içine konularak üzerinin ve çukurun toprakla kapatılmasıdır (Leclerk ve Tarrete 1997, s. 1002-1003). Bu tür gömütlerde mezarın mimarisini çukur oluşturur. Bu nedenle, gömüt çukurunun açlmaya başlandığ1 seviyede izi tespit edilerek, içinin çukurun formu bozulmadan kazılması gerekmektedir. Cesedin gömülmesi sırasında dolgunun içine konulan organik şeylerin saptanmasında, cesedin çürüme ve dağılma dinamiklerinin tespitinde dolgunun kazılma aşaması belirleyicidir. Kazı aşamasında, iskeleti oluşturan kemiklerin yerinden oynatılmaması, eğer elde olmayan nedenlerle yerinden oynamalar söz konusu ise, bunların kemikler üzerinde işaretlenmesi, iskeletin yatırllış biçiminin doğru olarak tespit edilmesinde önem taşımaktadır (Crubezy, 2000, s. 21-22).

Gömütlerin kazılmasında kullanılan aletler. Ilıman bölgelerde, kuru toprak dolguyla çevrelenmiş iskeletlerin kazılmasında, büyük uzun kemikler için küçük mala, uzuvlar (kol-el-bacak-ayak), çocuk gömütleri ve son rötuşlar için dişçi aletleri, kazılan toprağın boşaltılması için ince firça ya da aspiratör kullanılması önerilmektedir (Crubezy, 2000, s. 21). Çamur, batakl1k dolgusu gibi nemli ortamlarda bulunan kemikler sslak ve yumuşamış olması nedeniyle kemiklerin ahşaptan ince aletler ile temizlenmesi, kemiklerin tahrip olmadan açılması için tercih edilmelidir (Yllmaz, 2011).

Kaydetme ve belgeleme. Belgeleme süreci, kazının başından sonuna kadar olan çalışmaların takip edilebilmesini sağlayacak biçimde, kazı esnasında kalıntıları in situ olarak görmemiş, belirli bir süre sonra bu veriler üzerinde çalışacakların da anlayarak, bilgi üretiminde kullanabilir nitelikte, objektif ve net olmalıdır. 
Tanımlamaların krokilerle desteklenmesi veya çekilen detay fotoğraflarıyla ilişkilendirilerek sunulması önem taşımaktadır. Belgelemenin üç temel bileşenini oluşturan kazı sırasındaki kalıntıların/buluntu topluluğunun detaylı tanımları, fotoğrafları ve çizimlerinin ilişkisel olarak arşivlenmesi elzemdir. İskelete ait bütün kemikler yerinden oynatılmadan açığa çıkarılmalı, her bir kemiğin duruş biçimi, anatomik duruşa uyumluluğu, yönü ve diğer kemiklerle eklemlenme durumu (dayaniklı ve dayanıksı eklemlenmeler) detaylı olarak not edilmeli ve fotoğraflarla desteklenmelidir. İskeletin yönü omurga aksına göre belirlenmelidir. İskeletin gömüt mimarisiyle ilişkisi ve varsa çevresindeki diğer nesnelere göre konumu belgelenmelidir. Ayrıca, gömütlerin bulundukları alanlardaki diğer arkeolojik kalıntılarla yatay ve dikey bağlantıları da mutlaka gerekçeleri açıklıkla yazılarak kurulmalıdır (Duday, 2005, 2011).

Fotoğraflama. Gömütün tespit edildiği zamandan başlayarak, gömüt yapısının, insan kemiği kalıntılarının vb. sınırları açığa çıktıkça, kemiklerin birbirlerine ve mezar mimarisine göre konumları, duruşları belirginleştiği, çalışmanın sonuna kadar, her aşamada kalıntıların, tepeden dik açıyla detay ve genel fotoğrafları çekilmelidir. Son fotoğraf ise iskelet, mezar mimarisi ve mezar içindeki diğer nesneler tümüyle açığa çıktı̆̆ında, her birinin diğerleriyle arkeolojik bağlamının görülebileceği genişlikte ve dik açıyla fotoğraflanmalıdır. Ayrıca kemiklerin birbirine göre konumunu, üst üste binmeleri, sıkışmaları, dayanıksız veya dayanıklı eklemlenme bölgelerini, patolojiler gibi detaylar, yakından ve odaklanılan bölüm net görülebilecek açıyla çekilmelidir. Detay fotoğrafları mutlaka genel fotoğrafla ilişkilendirilerek arşivlenmelidir (Fabre, 1996).

Çizim. Eğer arazide el ile çizim yapılması istenirse yetişkin gömütleri $1 / 10$, çocuk/bebek $1 / 5$, fetus ise $1 / 1$ ölçeğinde çizilebilir. Günümüz teknolojisinde çizimler bilgisayar ortamında yapılmakta ve istenilen ölçeğe çevrilebilmektedir. İskeletin yatırllış biçimine göre; tek veya birkaç aşamalı çizime ihtiyaç duyulabilir. İskeletteki farklı aşamalar, çizimler üst üste konularak gösterileceği için, her çizim evresinde aynı referans noktaları, değiştirilmeden/oynatılmadan korunarak kullanılmalıdır (Crubezy, 2000, s. 21).

Seviyelerin alınması. Gömüt mimarisi, dolgu yapısındaki değişimler, iskelet ve onunla ilişkili bütün kalıntıların seviyesi alınmalıdır. Toprağa açlan çukurlara yapılan ölü gömme uygulamalarında, çukurun kenarlarından ve dibindeki farklı yükseltileri gösterecek sayıda seviyeye ihtiyaç duyulmaktadır. Kemiklerde ise, iskeletin yatırılış biçimine göre alınacak seviye sayısı değişkendir. A priori olarak, her kemiğin duruş biçimini ve diğer kemiklere göre konumunu net olarak anlamamızı sağlayacak seviyelerin alınması zorunludur. Kafatasının üst kismından, alt kısmından ve alt çenenin alt ve üst kısmından; pelvisin duruş biçimine göre değişen sayıda; uzun kemiklerde, özellikle kol ve bacak kemiklerinin her birinden üst uç-orta-alt uçtan seviye alınmalıdır. Dayanıksız eklem bölgelerinin bulunduğu kemiklerin baş ve uç kısımlarının, kaburga kemiklerinin üst kısımlarının ve özellikle en alt kısımdaki kaburgaların seviyesinin alınması önerilmektedir (Crubezy, 2000, s. 21).

\section{İskelet koruma fişleri ve standart kayıtlar.}

Arkeotanatolojik yaklaşımda önerilen gömüt arazi kayıt formu; gömütün genel durumu, iskeleti oluşturan kemiklerin duruş biçimleri ve tafonomik durumları, ölü nesneleri vb., gömütün bütün bileşenleri ve arkeolojik bağlamlarıly ilgili yönlendirici sorular ve seçeneklere yer verilmiştir. Ayrıca, kemiklerin ve dişlerin korunma durumunu kaydetmek için bir bölüm bulunmaktadır (Courtaud, 1996).

Arazide alınacak biyolojik ölçüler. İnsan kemikleri bulundukları ortama göre farklı korunma durumları ile günümüzeulaşmaktadır.Bunedenlebiyolojikanalizleriçin gerekli ölçülerin, mümkün olduğunca arazide alınması, kemiklerin kaldırılması sırasında oluşabilecek tahribatlar nedeniyle eksik ölçü kalma riskini azaltmaktadır. Arazide alınan ölçüler laboratuvarda kontrol edilebilir. Pelvis kemiklerinden, erişkinlerde bireyin cinsiyeti güvenli yöntemlerle tespit edilebilmektedir. Bu nedenle mümkün olduğu durumlarda, cinsiyet belirlenimi için pelvisten gerekli ölçülerin (Brůžek, vd., 2017) arazide alınması, güvenli cinsiyet tayini için önemlidir. Aynı gerekçelerle uzun kemiklerden alınabilecek ölçülerinde arazide alınması önerilmektedir.

\section{Kemiklerin kaldırılması, örnek alınması, temizlenmesi ve korunması. Laboratuvarda yapilacak} çalışmalardan alınacak verim, araziden kemiklerin kaldırmasına gösterilen özen ve dikkat de belirleyicidir. Kemiklerin kaldırılmaya başlanmadan önce, tahrip olmuş/olabilecek kemikler, bulundukları yerde sağlamlaştırılmalıdır. Kullanılacak kimyasalın yoğunluğu kemiğin tahrip durumuna göre değişmektedir. Kimyasal uygulamalar yapılmadan önce, farklı analizler için mutlaka kemiklerden örnek alınmalı ve bunlar için gerekli belgelemeler (fotoğraf, çizim, form doldurma) yapılmalıdır. Kimyasal madde, kemik yüzeyler iyice temizlendikten sonra firça ile uygulanmaktadır. Kemikler kaldırilırken sağ ve sol tarafa ait kemikler ayrilarak arkeolojik bağlamıyla birlikte kemiğin ad, çift kemiklerden ise hangi tarafa ait olduğunu belirten, iskelet/kemik etiketleri kemiklerle birlikte torbalara 
konulmalıdır. Kemikler eğer tahrip olmuş ise nemlenme nedeniyle tahribatın artma olasılığına karşın kâğıt havlu veya tuvalet kâğıdına sarılmalı ya da kâğıt torbalara konmalıdır (Duday vd., 1990, s. 32; Duday, 1995, s.3738).

\section{Tekli birincil gömütler}

Bahsi geçen analitik araçlar, gömütlerin niteliklerini, arkeolojik ve tafonomik bağlamlarının birlikte değerlendirilmesini sağlamaktadır. $\mathrm{Bu}$ çalışmalardan elde edilen verilerin bütünü, ölü gömme uygulamalarının belirlenmesi yoluyla eski toplumların ölü gömme geleneklerinin oluşturulmasının alt yapısını oluşturmaktadır. Makalenin bundan sonraki bölümü, özellikle tekli birincil gömütlere odaklanmaktadır. Birincil gömüt, ölümden kısa bir süre sonra cesedin "sürekli" kalacağ1 yere gömülmesi ve bütün değişim sürecini orada geçirerek "günümüze" ulaşmasıdır. Bu özelliği nedeniyle bu mezarlar, tek yerli ve tek zamanlıdır. Açı̆̆a çıkarılan bir gömütün birincil kategoride sınıflanması için cesedin ilk gömüldüğü yerde yumuşak dokularının çürüme, dağılma ve iskeletleşme sürecini tamamladığını gösteren izlerin iskelet üzerinde saptanması gerekmektedir. Bunun için, iskeletin anatomik duruş analizi, dayanıklı ve dayanıksız eklem bölgelerinin durumu, gömüt mimarisi ve cesedin iskeletleştiği ortam dikkate alınmalıdır (Duday ve Sellier, 1990, s. 13; Duday vd., 1990, s. 31; Crubezy, 2000, s. 23; Boulestin ve Duday, 2005, s. 23-25; Peressinotto, 2007, s. 2; Duday vd., 2014). Kemiklerdeki yer değiştirmelerin tespiti için, öncelikle yumuşak dokuların yok olmas1, eklemlenmelerin sonlanması ve kemiklerin yer değiştirebilir duruma gelmesi gerekmektedir. Kemiklerdeki yer değişikliğinin ölümden birkaç hafta sonra gözlemlenebildiği dayanıksı eklemlenme bölgelerinin durumu bu nedenle birincil gömütlerin tespitinde önceliklidir (Boulestin ve Duday, 2005, s. 27; Duday, 2011, s. 26-27). Ölü gömme uygulamalar1 kapsaminda, ceset yakıldıktan (kremasyon) sonra, geriye kalan kemikler bir kabın (urne) içine veya başka bir şeye konularak gömülmektedir. Bu uygulama doğrudan ikincil gömüt kategorisinde değerlendirilmektedir (Grévin, 2004; Duday, 2011, s. 145). Baz1 arkeolojik kaz1larda ise, toprağa açılan çukurların içinde kremasyondan geriye kalan kemikler açı̆̆a çıkarılmaktadır (Y1lmaz, 2011). Bu kalıntı grubunun ise, birincil gömüt olma durumunun saptanması için (cesedin ilk konulduğu yerde yakılarak, sonrasında kemiklerin yeri değiştirilmeden aynı yere gömülmesi) korunan kemiklerin anatomik pozisyon analizini, eklemlenme bölgelerinin durumu ve etrafındaki dolgudaki yanma izleri dikkate alınarak değerlendirilmelidir (Duday, 2011, s. 152-153). Kazılarda açı̆̆a çıkarılan insan kemiğgi kalıntılarında iskelet sistemini oluşturan kemikler, bireyin yatırılış biçimine göre anatomik biçime uygun ve yerinde ise, iskelet birincil kategoride sinıflanmaktadır (Duday, 2011, s. 25 30; Duday vd., 2014, s. 237). Ancak, iskeletin tümüyle anatomik duruşunu korumaması, kemiklerin yer değiştirmiş olması ise tek başına, birincil gömüt olmadığ1 anlamina gelmemektedir. Anatomik duruş, kimi zaman gömüt ortamından kaynaklanan doğal etkenlerle, kimi zaman başka bir bireyin belirli bir süre sonra aynı alana gömülmesi için ve özellikle de cesedin "boş bir ortamda mı yoksa dolu bir ortamda mı" iskeletleştiğine göre de farklılaşmaktadır (Duday, 1995).

\section{Cesedin tafonomiksürecinigeçirdiğiortam:Gömüt} yapısı veya mimarisi. Ölünün, içine konduğu ortam ve çevresinin niteliği cesetten-iskelete dönüşümünde belirleyici rol oynamaktadır. Gömülmeden önce, gömülme sırasında ve gömüldükten sonra yapılan iradî uygulamalar, doğrudan gömütü hedef almaz; ancak gömütün etkilendiği dolaylı insan müdahaleleri ve doğal ortamdan kaynaklanan oluşumların sonuçları, arkeolojik kazılarda açı̆̆a çıkarılan gömütlerde karışmış olarak karşımıza çıkmaktadır (Duday, 2011). Bu karışıklığ1 ayrıştırarak, incelenen topluluğun/toplumun ölü gömme geleneklerini oluşturan insanların iradî uygulamalarını ortaya koymak, gömütlerin kazılmasının temel amacıdır. $\mathrm{Bu}$ belirlemelerin yapılabilmesi için ölülerin konduğu ortamlarda, doğal süreçlerin sonucunda iskelet üzerinde bıraktığ1 izlerin ayırt edilebilmesi önem taşımaktadır. Strüktürveya yap1 "kalıntıların birlikte organize edilmesi" olarak tanımlanmaktadir (Leclerc ve Tarréte, 1997, s. 1044). Bu yalın ilkeyi temel alarak değerlendirdiğimizde, genel olarak cesedin görünür olmasını engellemek için diğer insanlar tarafindan oluşturulan ve cesedi çevreleyen her şey gömütün yapısını veya mimarisini oluşturmaktadır. Gömüt veya mezar, cesedin bilinçli olarak belirli bir sınır içine alınmasıdır; ölü gömme uygulamasının başlangıcı kabul edilen, işte tam da bu insan ölüsünün, çağdaşı yaşayanlar tarafindan bilerek/ isteyerek bir sınır içinde "korunduğuna" dair izlerin tespit edilmesini temel almaktadır. Bu nedenle -niteliği ne olursa olsun- gömüt yapısı, ölünün gömüldüğünün önemli göstergelerindendir (Tillier, 1990; Duday ve Sellier, 1990, s. 12; Henry-Gambier, 2008, s. 41). Bedenin yatırılış biçimi, onu sınırlandıran öğeler ve onu çevreleyen ortam, cesedin iskelete dönüşmesinde doğrudan etkilidir. Gömüt mimarisi/yapısı iki kategoride ele alınabilir. Bunlardan ilki gömütün neyle ve nasıl sınırlandığını ayrıştırmayı hedefler. Bunu diş çeper veya çevre sınırı da denilebilir. Bu grup toprak, çanakçömlek, ahşap ve taş olabileceği gibi bu malzemelerin karmasından da oluşabilir. Ayrıca tümülüs, kurgan ve dolmen gibi anıtsal mezar yapıları da söz konusudur (Leclerc ve Tarréte, 1997, s. 1002). İkinci kategori ise diş çeperin içindeki durumu anlamaya yöneliktir. Ceset "nasıl bir alana konmuş ve hangi koşullarda 
günümüze kadar ulaşmıștır” sorusuna odaklanmaktadır. $\mathrm{Bu}$ soru arkeolojik kazılardan elde edilen verilerle yanıtlandı̆̆ında, eldeki bulgular birincil gömütlerdeki cesetlerin iskeletleşme süreçlerini; etrafı dolu bir alanda, etraf1 süreç içerisinde dolmuş bir alanda ve etrafı boş bir alanda olmak üzere üç farklı kategoriye ayrılmaktadır (Duday, 1990, s. 194; Duday, 1995, s. 44-52).

Cesedin dolu bir alanda iskeletleşmesi. Dolu bir alanda iskeletleșen cesetlerde, ağırlıklı olarak bedenin etrafinın gömüldükten hemen sonra toprakla doldurulduğu düşünülmektedir. Bu veri, ölü gömme geleneklerinin yeniden kurulabilmesi açısından önemlidir. Dolu bir ortamda iskeletleşmenin tespitinde gömüt mimarisinin yapısına, iskelete göre boyutuna, cesedin gömüte yatırılış biçimine ve bu duruma bağlı olarak kemiklerin birbirine göre konumu dikkate alınmalıdır (Duday, 1990, s. 194; Duday, 2011; Duday vd., s. 2014). Toprak dolgunun oluşturduğu ağırlık, yumuşak dokuların çürüme sularının toprağa karışması ile oluşan nemlenmenin etkisiyle toprak şişmekte, çürüme sürecinde biyolojik olarak zenginleşen toprak, büyük ölçüde canlıları kendine çekmektedir. Bu etkenler sonucunda cesedin içinde olduğu dolgu, etrafindaki dolgudan renk ve doku açısından farklılaşmaktadır. Bu durum gömüt çukurunun sınırlarının belirlenmesinde de kullanilabilmektedir (Duday vd., 1990, s. 39). İnsan bedeninde, iç organların yerleștiği boșluklar söz konusudur (Süzen, 2013, s. 7) ${ }^{5}$. Cesedin iskeletleşme sürecinde etrafı dolu bir alana gömülmüș olsa bile organların yok olması sonucunda, bu anatomik boşluklar ortaya çıkmakta ve dolgu basincının da etkisiyle kemiklerin yerlerinin değişmesiyle sonuçlanabilmektedir. Gömütün mimari yapısı ve boyutu cesedin iskeletleşmesi ve eklemlenmelerin sonlanma sürecinde etkilidir. Gömüt alan1, cesedin boyutuna göre dar ise kemikler üzerinde sıkışma etkisi oluşturarak kemiğin anatomik duruşunda farklılașmalara yol açabilmektedir. Gömüt alanı, cesedin boyutuna göre geniş ise, bu durumda da kemiklerde açılmalar ve kaymalar için alan bulabilmektedir (Duday, 2011).

Anadolu Arkeolojisi'nde ölüler, dönemlere göre farklılık göstermekle birlikte, Çanak Çömleksiz Neolitik Dönem'den başlayarak evlerin içinde taban altlarına, yerleşim içinde mekânlar arasındaki açıklıklara ve toprağa açılan çukurların içine gömülmektedir (Yılmaz, 2000). Özellikle mekân içlerinde taban altlarına ölüler gömüldükten sonra, yaşayanlar tarafından "ölü gömülen mekânın kullanımının devam edip etmediği" mekânın niteliğinin belirlenmesinde önemlidir.

5 İnsan bedenindeki anatomik boşluklar kafatası, omurga, göğüs, diyafram, karın ve leğen boşluklarıdır (Süzen, 2013, s.7).
Ölüler gömüldükten sonra yerleșim içi, mekân içi veya mekân dışındaki alanlara aktif kullanıma devam edilecekse, ölülerin gömüldükten sonra etraflarının toprakla doldurulması beklenebilir. Özellikle, cesedin iskeletleştiği ortam, gömüt yapısı ve dolgu birlikte değerlendirildiğinde, incelenen toplumun ölü gömme uygulamalarının tespit edilmesinin yanı sıra, yaşadıkları alanları kullanım biçimleri hakkında üretilecek hipotezlere de önemli katkılar sunacaktır.

\section{Bulgular}

\section{Cesedin tekil birincil gömütlerde toprağa açılan} çukurlarda etrafı dolu bir ortamda iskeletleşmesi

2012 y1lında, Marmaray Projesi içerisinde, Gebze-Halkalı Banliyö Hatlarının Iyileştirilmesi çalışmaları sırasında, Pendik Höyük'te kurtarma kazıları yapılmıştır. Pendik Höyük'ün, 1908'de Bağdat Demiryolu'nun inşaatı sırasında, Miliopulos adlı işçi tarafından keşfedildiği belirtilmektedir. Pendik Höyük'ün günümüzde denize mesafesi yaklaşık 50 metredir. Temenye Burnu'nun doğusundaki kıyı hattında yer almaktadır. Son kazılarda yerleşmede toplam 64 mezar (53 Çanak Çömlekli Neolitik, 11 Bizans Dönemi) tespit edilmiştir (Kızıltan, 2015a, s. 369). Baz1 mezarlarda birden fazla birey bulunmaktadır. Henüz birey sayısı belirleme çalışmaları tamamlanmamıştır. Çanak Çömlekli Neolitik Dönem yerleşiminin ölü gömme uygulaması; birkaç istisna dışında, toprağa açılan çukurların içinde tekli birincil gömüttür (Resim 1).

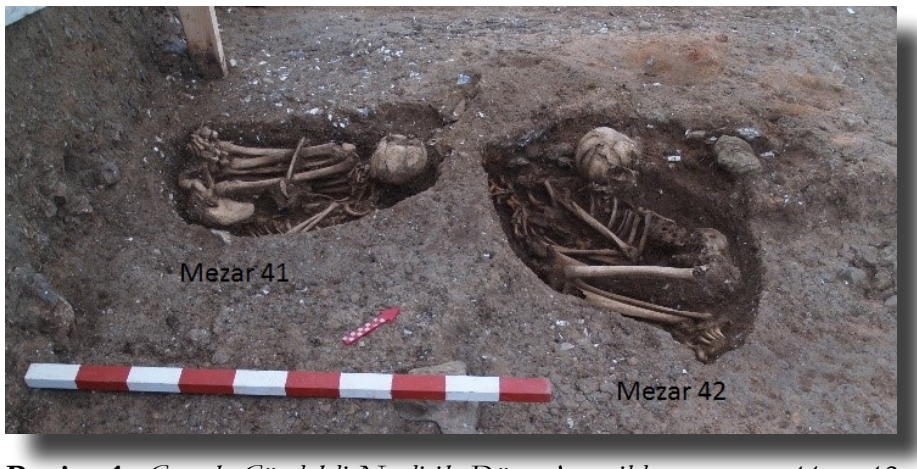

Resim 1. Canak Cömlekli Neolitik Dönem'e tariblenen mezar 41 ve 42 (Fotoğraf: Sinan Yiğit | Istanbul Arkeoloji Müzeleri Müdürlügü Pendik kaž arsivi)

Pendik Höyük 41 nolu mezar, toprağa açılan çukur içerisinde tekli birincil gömüt, kuzeydoğugüneybatı doğrultusunda yatırılan bir bireye aittir. Birey, çok büzülmüş biçimde (pelvis-femur açıs1 $90^{\circ} \mathrm{den}$ küçük) gövde kısmı sırt üstü, alt uzuvlar sağ tarafina yaslanmıs, üst uzuvlar bükülerek eller kafatasının atında birleştirilmiş, yüzü kuzeybatıya dönüktür (Resim 1 ve 2).

İskelet sistemini oluşturan kemikler genel olarak anatomik pozisyonda ve yerinde korunmuștur. Mezar mimarisini yuvarlağa yakın bir çukur oluşturmaktadır. 


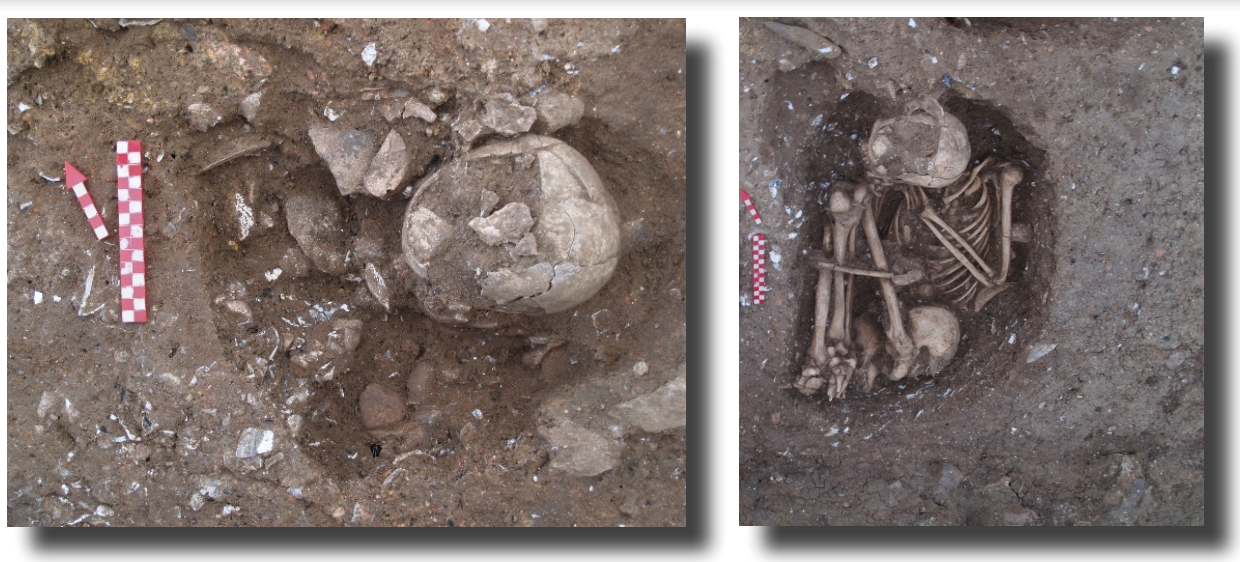

Resim 2. Pendik Höyük 41 nolu mezar

(Fotoğraf: Yasemin Yılmaz. I İstanbul Arkeoloji Müzeleri Müdürlï̈ü Pendik kazı arşivi)

Çukur gövdeye göre dardır. Bu durum özellikle sol üst uzuvlarda bir sıkışma ile kendini göstermektedir. Sol humerustaki dönüş ve sol klavikulanın yatay duruşu ve humerusla $90^{\circ}$ lik açısının bozularak hafif düşey hale gelmesinden anlaşılmaktadır. Sol üst uzuvlarda belirlenen bu değişim dar bir alana konulan ve etrafi toprakla doldurulan iskeletler üzerinde saptanan bir değişim olarak değerlendirilmektedir (Duday, 1995, s. 48). Sinır etkisi ve cesedin dolu bir ortamda iskeletleştiğine dair izler sol pelvis ve alt uzuvlarda da gözlenmektedir. Sol pelvis dikey durumdadır. Alt uzuvlar ise çukurun kenarının da etkisiyle iyice gövdeye doğru çekilmiştir. Patellaların duruşu dengesiz/yer değiştirebilir olmakla birlikte anatomik yerindedir. Kafatasının sıkı anatomik duruşunu koruması da cesedin dolu bir ortamda iskeletleştĭginin göstergesidir (Resim 2).

Pendik Höyük'te 42 nolu mezar, toprağa açlan oval biçimli çukurun içerisinde tekli birincil gömütte bir erişkin bireye aittir. Kuzeybat1-güneydoğu doğrultusunda, sağ tarafı üzerine, üst uzuvlar ve alt uzuvlar gövdeye doğru çekilmiş, çok büzülmüş (pelvisfemur açısı $90^{\circ}$ den küçük) biçimde yatırılmıştır. Kafatası hariç, özellikle dayanıksız eklemlenme bölümlerindeki kemikler de dâhil olmak üzere iskeleti oluşturan kemikler, anatomik yerindedir. Patellalar, el ayak tarak ve parmak kemikleri, cesedin etrafı dolu bir ortamda iskeletleştiğini göstermektedir. İskelet için açılan çukur gövdeye göre, özellikle de 41 nolu mezarla kiyaslandığında daha geniştir (Resim 3). Gömüt içerisinde saptanan "aykırı" iki farklı durum söz konusudur. Bunlardan ilki birincil bağlamdaki iskeletin omurga aksı üzerinde duran kafatası; ikincisi ise, kafatasının hemen altında bulunan sol tarafa ait tüm pelvis kemiğidir. Kafatası ve sol pelvis kemiği kime aittir? Gömütün içerisinde korunmuş birincil bağlamdaki iskeletin kafatası eksiktir. $\mathrm{Bu}$ nedenle öncelikle kafatasının bu bireye ait olma durumu değerlendirilmiştir. Kafatasında oksipitalin ve atlasin eklemlenme yüzeyleri birbiriyle uyumlu, kafatası ve birincil bağlamdaki iskeletin tafonomik özellikleri benzerdir. $\mathrm{Bu}$ nedenle kafatasının birincil bağlamdaki bireye ait olması kuvvetle muhtemeldir. Kafatasının yerinden oynama durumunu nasıl değerlendirilmelidir? Boyun omurları dayanıksız eklemlenme bölgelerindendir ve ceset gömüldükten sonra, Türkiye'nin de içinde bulunduğu iklim kuşağında, toprağa açılan çukurların içerisine konularak üzeri kapatılan cesetlerin birkaç hafta içerisinde yumuşak dokular yok olarak kafatasının omurga aksiyla eklemlenmesi sona ermektedir (Duday, 2011, s. 27). Eklemlenmelerin sonlanmasiyla, kafatasının duruş biçimine de bağlı olarak gömüt alanı içerisinde boş alanlar olduğunda kafatası doğal olarak yer değiştirebilmektedir (Mickleburgha ve Wescott, 2018). 42 nolu mezardaki iskelet analiz edildiğinde, özellikle dayanıksız eklemlenme bölümlerinin duruş biçimi, genel olarak dolu bir ortamda yumuşak dokuların yok olma ve iskeletleşme sürecini geçirdiğini göstermektedir. Bununla birlikte, çukurun içindeki toprak yeni doldurulduğu zamanlarda çok sık dokulu olmadı̆̆ında, gömüt içerisindeki kısmi boşluklar ve dolgunun kafatası üzerindeki olası itme durumu ve yer çekiminin etkisiyle yer değiştirmesi kuvvetle muhtemeldir. Özellikle arkeotanatolojik yöntem çalışmalarında, iskelet sistemini oluşturan kemiklerde, doğal olarak yer değiştirmelerle ilgili verilere dikkat çekilmekte, doğal tafonomik olgular ve ölü gömme uygulamalarının ayrıştırılmasının önemi vurgulanmaktadır (Duday, 1995; Mickleburgha ve Wescott, 2018). Pendik Höyük'teki 42 nolu mezarda, kafatasının gömüt içerisinde doğal olarak yer değiştirdiği hipotezini destekleyen veriler ağırlıktadır. Arkeotanatolojik ve deneysel çalışmalar, eklemlenmesi sonlanan kemiklerin, gömüt içerisinde boş alanlar olduğunda kolaylıkla yer değiştirdiğini göstermiştir (Duday, 2005, 2011; Peressinotto, 2007; Mickleburgha ve Wescott, 2018). Birincil bağlamdaki iskeletin pelvisinin sağ ve sol kısımları anatomik pozisyonda korunmuştur. Kafatasının hemen altında bulunan sol coxa ikinci bir bireyi temsil etmektedir. İkinci bireyi temsil eden bu parçanın Mezar 42'nin hemen yanında 

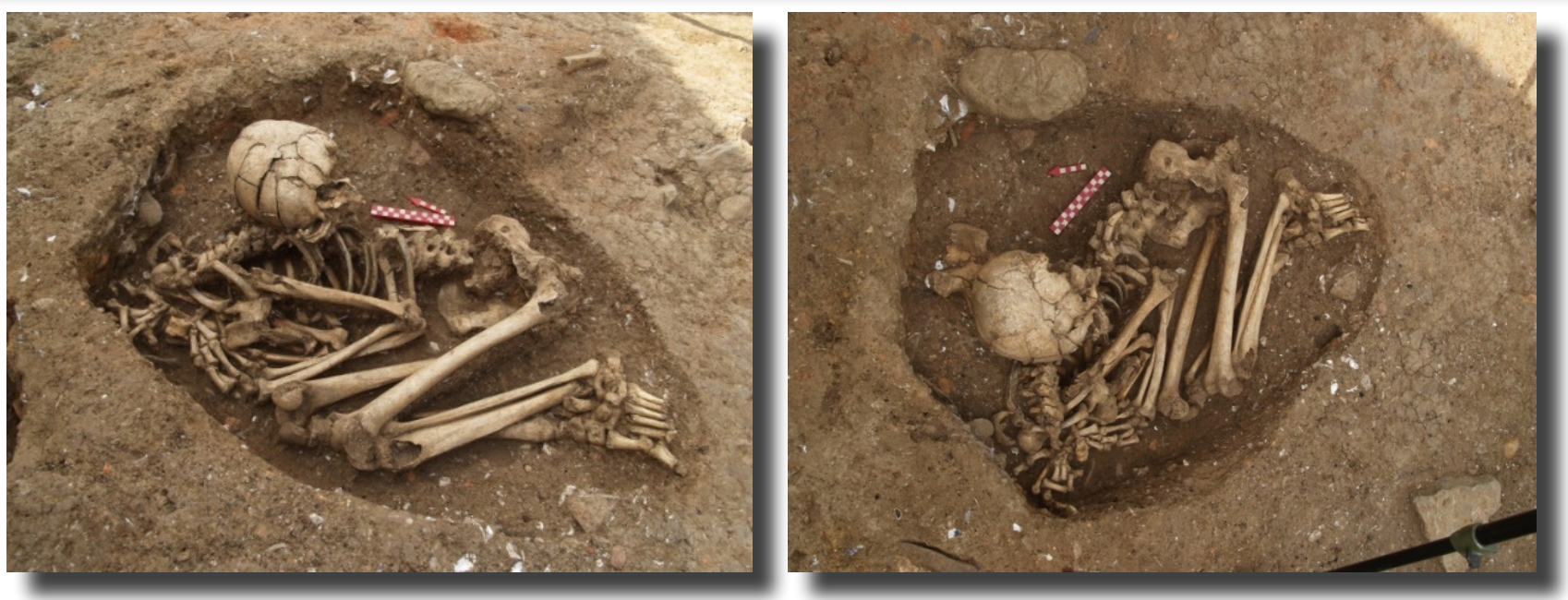

Resim 3. Pendik Höyük 42 nolu mezar. Sağdaki fotoğrafta kafatasinn aldnntaki ikinci coxa parçası görülebilmektedir (Fotoğraf: Sinan Yiğit | İstanbul Arkeoloji Müzeleri Müdürlügü Pendik ką̨ arşivi)

daha alt seviyedeki bir gömüte ait olma durumunu değerlendirmek için çukurun sınırları genişletilmiş, ancak başka kemik bulunamamıștır. Bu durumda ikinci bireyi temsil eden kemik "izole" dir.

\section{Hasıra sarılı olarak dolu bir ortamda tafonomik sürecini tamamlayan tekli birincil gömüt}

Ölünün bir nesneye sar1lı olarak gömülmesi, cesedin iskeletleşme sürecinde etkili olan nedenlerdendir. $\mathrm{Bu}$ nesne kimi zaman iskeletler üzerinde doğrudan izler birakmakta, bazı durumlarda ise kemiklerdeki yer değişikliklerinden hareketle, cesedin iskeletleşme sürecinde yok olmuş nesneler hakkında fikir oluşturmamızı sağlamaktadır (Duday, 1995, s. 3738). Anadolu'da yapılan kazılarda, Çanak Çömleksiz Neolitik Dönem'den başlayarak, cesedin hasıra vb. nesnelere sarılma uygulaması tespit edilmiştir (Yılmaz, 2002; Büyükkarakaya, 2019). Çanak Çömleksiz Neolitik Dönem'e tarihlenen Aşıklı Höyük'te 1989-2000 y1lları arasında yapilan kazılarda 65 bireyi temsil eden iskelet kalıntıları açığa çıkarılmıștır. Bunlardan 42'si erișkin ve 23'ü erişkin olmayan bireylere aittir. Hasır kalıntıları, tümü erişkinlere ait 12 bireyde belirlenmiştir. Eldeki veriler, hasırın standart bir kullanımının olmadığını, cesedin yatırılış biçimine göre değişiklik gösterdiği yönündedir. Bu gömütlerde ortak olan durum; hasırın varlığının cesedin tafonomik sürecine etki etmesidir. Tona Majo (1995) tarafindan kazılan ve belgelenen iyi korunmuş hasırlı birey örneği, referans niteliği taşımaktadır (Yılmaz, 2002).

M.Ö.8.binylla tarihlenen(Esin, 1998)ikincitabakada, 3J açmasında, I odasının içinde batı tarafta, 2c evresine tarihlenen tabana açılan, yuvarlak planlı çukurun içinde açığa çıkarılan, SK 109 nolu erişkin erkeğe ait iskelet, çukurun güney sınırına paralel, güney ve batı kenarlarına yaslanacak biçimde gömülmüştür. İskelet omurga aksına göre, kafatası batıda, yüzü güneydoğuya dönük, ayaklar doğuya gelecek biçimde bat1-doğu doğrultusunda yatırılmıstır (Resim 4) Ölünün bel ve sırt omurları çukurun tabanı üzerindedir; boyun omurları ise çukurun batı sınırına yaslanarak dönmektedir. Kafatası anatomik yerinden biraz öne doğru kaymış olup pariyetaller ve oksipital üstte görülmektedir. Özellikle frontal kısmında ise hasır izi ve hasırın dokunma tarzı belirgindir (Resim 4). Kafatasının, dayanıksız eklemlenme bölümlerinden olan boyun omurlarıyla bağlantısı, gömüldükten sonra görece daha kısa sürede sonlanmıştır. Ölü, olasılıkla ilk gömüldüğü zamanlarda, hasırın toprağın sızmasını engellemesi sonucunda oluşan boş alanlar ve kafatasının duruş biçiminin de yer değiştirmeye uygun olması nedeniyle, omurların üzerine doğru kaymış, mandibulaya yaslanmıştır. Üst uzuvlar omurga aksına paralel uzanmakta, eller pelvisin önünde birleşmektedir. El kemikleri yerinden oynamayarak anatomik duruşunu korumaktadır ve bu, cesedin iskeletleşme sürecini dolu bir ortamda geçirdiğini göstermektedir. Alt uzuvlar gövdeye doğru çekilmiştir. Birey yarı büzülmüş biçimdedir (pelvis-femur açısı $90^{\circ}$ den büyük) ve ayak tabanları yere basmaktadır. Patella kemikleri anatomik yerinde ve duruşundadır. $\mathrm{Bu}$ durum iskeletleşme sürecini etrafi dolu bir alanda tamamlamasının sonucu ve hasıra "sarılı" olmanın etkisini de göstermektedir. Pelvis anatomik yerindedir. Duruş biçimi özellikle sırt üstü yatırılmış ve yumuşak dokular yok olduktan sonra, etrafinda boşluklar olduğunda, doğal olarak coxaların iki yana doğru açılmasına (Duday, 2011) iyi bir örnek oluşturmaktadır. Cesedin iskeletleşmesi ve devamında eklemlenmelerin sonlanmasiyla pelvisin çevresinde oluşan boş alanların toprakla hızlıca dolmasını hasırın varlı̆g1 "engellemiş" ve "ikincil boş alanlar" korunmuş olabilir. Coxaların iki yana doğru açılmanın sonucunda femurlarda bir yer değişikliği olabilmektedir. Ancak bu iskelette bu durum saptanmamıştır. İskeletin boyutuna göre gömüldüğü çukur hayli geniştir, kuzey tarafina 


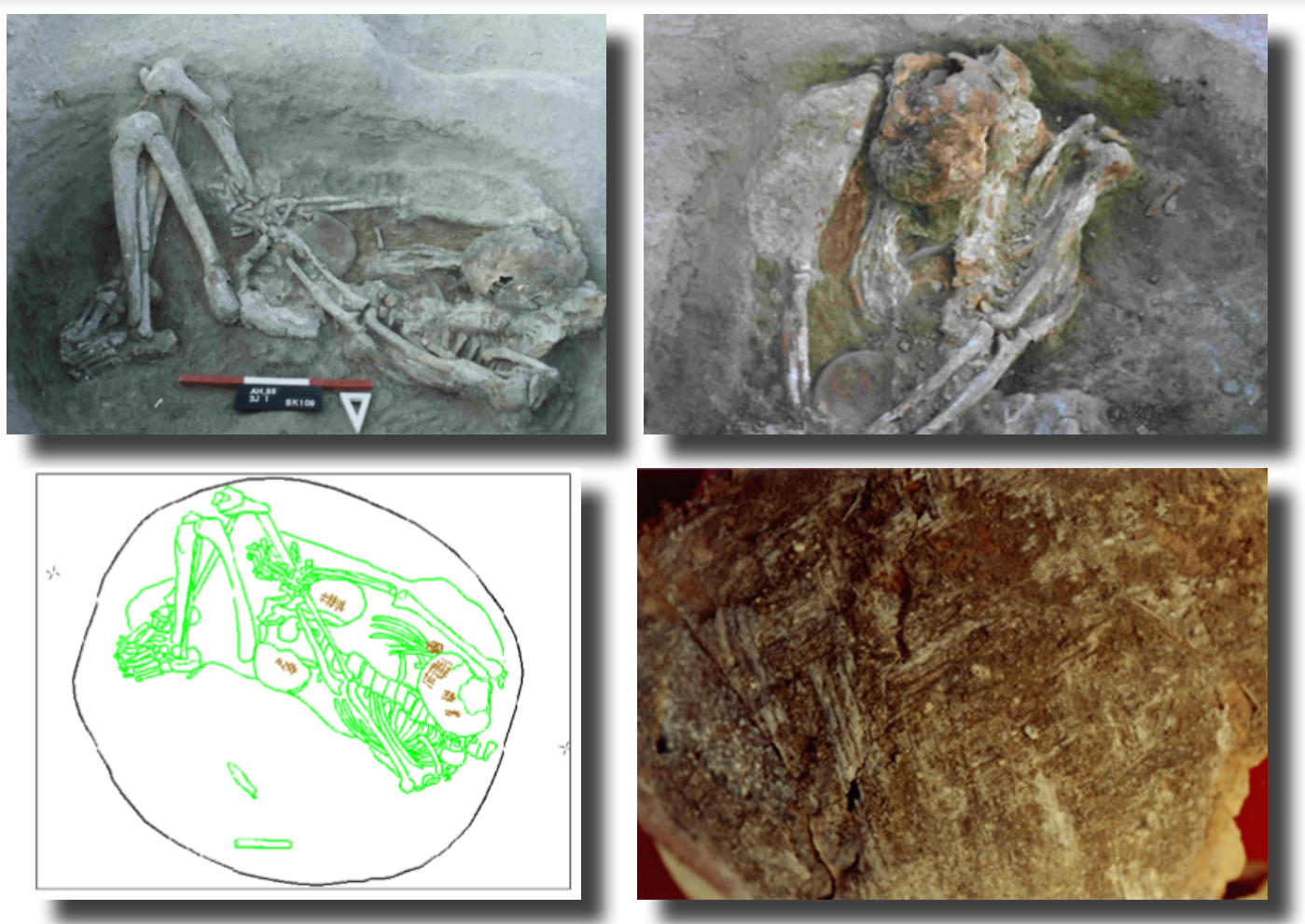

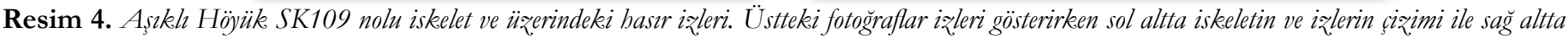
izlerin yakın görüntüsü görülebilir (Aşıllaböyük kazı arşivi)

"başka bir bireyin" gömülmesi için boşluk bırakılmış izlenimi oluşturmaktadır. Gömüt çukurunun tabanı, mekân tabanından $30 \mathrm{~cm}$ derinliktedir. SK 109 iskeletinin bulunduğu kısımda, I odasının tabanının korunmadığ ve çukur izlerinin tabanın alt kısmında, çöküntü biçiminde takip edilebildiği belirtilmektedir. Bu durum SK 109'un bu alana gömüldükten sonra, I mekânının tabanının yenilenmediğinin önemli bir göstergesidir. Çukurun, cesedin konduğu güney kısmında dolgunun daha sık dokulu olması içinde kil ve kerpiç parçalarının bulunmasına karşın, çukurun boş olan kuzeyde tarafinda ise, dolgu içerisinde organik maddelerin daha yoğun olması, boş alanda ölünün yanına süreç içerisinde yok olan bir şeylerin konmuş olması muhtemeldir (Yılmaz, 2002).

\section{Cesedin dolu bir ortamda iskeletleşmesi ve mezar mimarisinde ahşap kullanımı}

Ahşap, organik yapisı nedeniyle arkeolojik kazılarda nadir olarak günümüze ulaşabilen kalıntılardandır. Anadolu Arkeolojisi'nde eldeki verilere göre, Neolitik Dönem'den başlayarak gömütlerin yapisında ahşabın kullanıldığına dair izler mevcuttur (Yılmaz, 2011). Özellikle Bizans Dönemi’ne tarihlenen mezarların bir bölümünde, cesedin ahşap bir tabutun içerisine konularak gömülmesi söz konusudur. Bu mezarlarda, başlangıçta cesedin etrafinda olan "sınır", süreç içerisinde ahşap yok oldukça ortadan kalkmaktadır. Ahşap, özellikle insan iskelet sistemindeki dayanıksız eklemlenme bölümlerinden daha yavaş yok olmakta ve kapladığı alanda ortaya çıkan "ikincil boşluklar" ve toprağın etkisiyle kemiklerde yer değiştirmelere neden olmaktadir (Duday, 1995, s. 44-47).

İstanbul'da Marmaray Projesi kapsaminda Yenikapı'da yapılan kazılarda, günümüz deniz düzleminin -6,30 m altında, Likos Deresi ile bağlantılı küçük bir kolun bataklık dolgusu içerisinde Çanak Çömlekli Neolitik Dönem'e tarihlenen kültürel kalıntılar belirlenmiştir. Anadolu Arkeolojisi'nde bataklık ortamında yapılan tek örnek olan bu kazı, normal koşullarda arkeolojik dolgularda bulunmasina alışılmamış organik kalıntıların iyi biçimde korunmuş olarak günümüze ulaşmasını sağlamıştır (Kızıltan ve Polat, 2013, s. 4-14; Kızıltan, 2015, s. 338). Yerleşimde toprağa açılan çukurlarda, gömüt yapısında ve ölü nesnesi olarak ahşap kalıntılar açığa çıkarılmıştır. Bu kategoride kazılan dört gömütün tümünde ahşabın farklı kullanımları belirlenmiştir. Çanak Çömlekli Neolitik tabakalardaki gömütler, bataklık dolgusunun kazılma teknikleriyle uyumlu olarak; ahşaplar, sünger ve su kullanılarak açığa çıkarılmıştır. Yenikapı'daki dört gömütten özellikle ikisi ahşabın mezar yapısına ve cesedin iskeletleşme sürecine etkileri açısından referans olarak kullanilabilecek niteliktedir. Yenikap1 Metro kazı alanında Gömüt 3, SK 7 olarak adlandırılmıştır. Toprağa açılan oval planlı, tabanı düz bir çukurun içerisinde, omurga aksina göre güney-kuzey doğrultuda, erişkin erkek birey, sol tarafı üzerinde büzülmüş (pelvisfemur açıs1 yaklaşık $90^{\circ}$ ) yüzü batıya dönük olarak yatırılmıştır. Kollar bükülmüss, eller kafatasının altında 

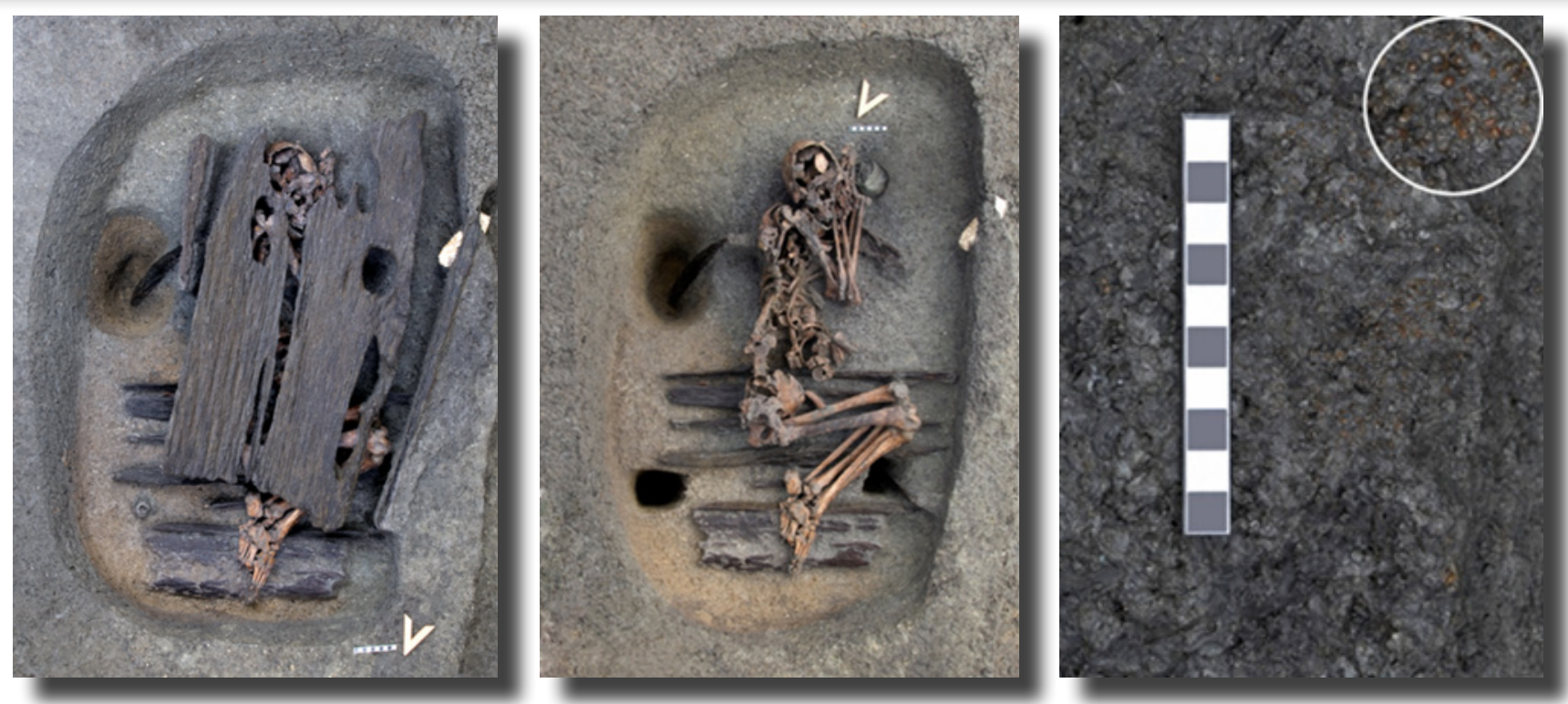

Resim 5. Yenikapı Kąısı 3 nolu gömüt SK 7. En solda abşabın altında yatan iskelet, ortada açı̆ga çıarılan iskelet ve en sağdaki dairenin için arkeontonaik

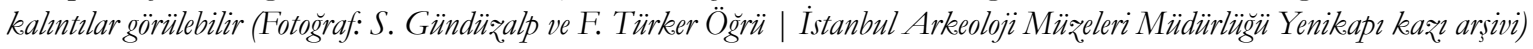

birleşmektedir. Mezar yapısında "estetik ve işlevsell" olarak ahşabın kullanım biçimi ve kafatasının hemen yanında bulunan küçük kabın içerisindeki botanik kalıntılarıyla ayırt edici özelliktedir (Y1lmaz, 2011, 2014). Ceset, alt uzuvlardan yatay olarak yerleştirilmiş dokuz parça ahşabın üzerine yatırılmıştır. Ceset gömüldükten sonra etrafinın toprakla doldurulmuş olması nedeniyle bunlar cesedin iskeletleşme sürecinde doğrudan etkili olmamıştır. Özellikle dayanıksız eklemlenme bölgelerinde kemikler tümüyle anatomik yerinde ve duruşunu korumuştur. $\mathrm{Bu}$ durum, cesedin iskeletleşme sürecini etrafı sık dokulu bir dolguyla dolu bir ortamda geçirdiğini düşündürmektedir. Cesedin tafonomik süreci üzerinde, özellikle ayaklar haricinde gövdeyi örtecek biçimde, cesedin etrafi toprakla doldurulduktan sonra yerleştirilen ahşap etkili olmuştur. Resim 5’te görüldüğü üzere özellikle ahşabın omurga aksına basınç uygulaması sonucunda, yumuşak dokuların yok olması ile karın kısmında ortaya çıkan boşluklara doğru özellikle alt sirt omurlar1, bel omurlar1 ve alttaki kaburga kemikleri kaymıştır. Kemiklerdeki yer değiştirmelerin iskeletin arkasındaki anatomik hacminin dışına taşmaması, bu kısımların toprakla doldurulduğunun önemli göstergelerindendir. Bu gömüt, dolgunun, ahşabin ve insan bedenindeki anatomik boşlukların etkileşimli olarak cesedin iskeletleşme sürecindeki etkilerini ortaya koymamızı sağlamıştır ve gömüt analizlerinde referans olarak kullanılabilir. Kafatasının ve ellerin yanında, yüzün dönük olduğu batı tarafa yerleştirilmiş olarak tam, küçük bir kap açığa çıkarılmıştır. Kap, içerisinde botanik kalıntılarla birlikte -belki de "yiyecekle"- mezara konmuştur. Kabın içerisinden dökülen botanik kalıntılar, dolgunun içerisinde kafatasının ve kolların önünden aşağıya doğru aktığı hat dolgu toprağında belirlenmiştir. Botanik kalıntılar küçük çekirdekler biçimindedir, arkeobotanik çalışmalar sonuçlanmamıştır. İskeletlerle birlikte açığa çıkarılan kapların (en azından bazılarının) "boş" konmamış olduğuna dair ender örneklerdendir (Resim 5).

\section{Cesedin tekli birincil gömütlerde etrafı boş bir alanda iskeletleşmesi}

Arkeolojik kazılarda eğer insan kemiği kalıntılarının çevresinde dolgu yok ise ve birincil gömüt bağlamında olduğuna dair veriler mevcut ise, bu durum cesedin doğrudan boş bir alanda iskelete dönüştüğü anlamına gelmektedir. $\mathrm{Bu}$ özellikle gömütün mimarisi ile doğrudan bağlantılıdır. Örneğin, taş lahitlerin içine ceset konulduktan sonra üzeri bir taş kapakla kapatıldığ1 durumda, lahidin içine toprağın sızabileceğinden ve açık kısımlar olmadığından iskeletin çevresinde çok az toprak olmaktadir. Bu durum da cesedin iskeletleşme ve dağılma sürecini boş bir alanda tamamladığı anlamına gelmektedir. Bu grupta açığa çıkarılan gömütlerde, kemikler ağırlıklı olarak anatomik duruşta ve yerinde korunmaktadır. Bununla birlikte bazı kemiklerde yumuşak dokuların çürümesi sonucunda uygun ortam olduğunda yer değişiklikleri gözlenmektedir.

Anadolu Arkeolojisi'nde, Çanak Çömlekli Neolitik Dönem'den itibaren ölüler pişmiş toprak kapların/ küplerin içine konularak gömülmektedir (Yllmaz, 2011; Büyükkarakaya, 2019). Çanak-çömlekler süreç içerisinde basıncın etkisiyle çatlamakta, kırılmakta ve zamanla küplerin içi ve insan kemiklerinin çevresi yavaş yavaş toprakla dolmaktadır. Kazıda, küplerin kırılan parçaları kaldırıldığında, içinde genellikle elenmiş gibi görünen, çanak-çömleğin kırılan kısımlarından süzülerek içeri dolan, gevşek dokulu ince taneli bir dolgu ile karşılaşılmaktadır. İskeleti oluşturan kemikler arasındaki eklemlenmelerin sonlanmasıyla kemiklerin 
seyyar duruma gelmesi, kemiklerin çevresinde boş alanların olması ve küpün içine süreç içerisinde süzülen toprağın itici etkisiyle kemikler yer değiştirmektedir. Cesedin kabın içine konma biçimi, kabın/küpün şekli de kemiklerin oynama yönünü ve biçimi üzerinde etkilidir.

Garzan Çayı'nın batı yakasında yer alan Çemialo Sırtı, Batman İli, Beşiri İlçesi, Yazıhan Köyü Gedikli Mahallesi'nin $1 \mathrm{~km}$ güneydoğusundadır. Deniz seviyesinden yüksekliği 503-512 metredir. Ilısu Barajı'nın suları altında kalacak bölgede olması nedeniyle kazılar yapılmıştır. Yerleşmede Orta Çağ, Demir Çağı (M.Ö. 1. bin) ve Orta Tunç Çağ (M.Ö. 2. bin) dönemleri mimarî ve farklı buluntu topluluklariyla temsil edilmektedir. Toplam 51 mezar gün yüzüne çıarılmıstır. Bunlardan 19 adedi küp mezar, 12 adedi taş çevirmeli mezar ve 20 adedi toprağa açılan çukur mezardır. Henüz kesin tarihler olmamakla birlikte mezarların çoğunluğunun M.Ö. 1. binyıla ait olması kuvvetle muhtemeldir. İki mezardan elde edilen kalibre edilmiş ${ }^{14} \mathrm{C}$ verilerine göre bu tarih M.Ö. 535-345'tir (Erim-Özdoğan ve Gündüzalp, 2018, s. 201-204; Yaka vd., 2018).

Çemialo Sırtı'nda açığa çıkarılan SK 26 numaralı erişkin kadına ait iskelet, iri bir küpün içerisinde, doğu-batı doğrultuda, kafatası doğuda, ayaklar batıda, sol tarafi üzerine çok büzülmüş olarak yatırılmıştır. Ceset iskeletleşme ve eklemlenmelerin sonlanmasinı başlangıçta etrafı boş, zamanla etrafinın dolduğu bir ortamda tamamlamıştır. Bu açıdan arkeotanatolojik yöntem çalışmaları için referans olarak kullanılabilecek "tipik" örneklerdendir. Küp yerinde yoğun olarak parçalanmış olup iskeletin çevresindeki toprak zamanla bu kırık kısımlardan içeri süzülmüştür. Küpün korunma durumundan görüldüğü gibi üstlerden ve özellikle küpün doğu kısmından toprak sızmasının daha yoğun olduğu, küpün batı tarafinda daha korunaklı kaldığı gözlenmektedir (Resim 6).

Üstteki küp parçaları kaldırılıp temizlendiğinde kemiklerde bir karmaşa ayırt edilmektedir. İskeleti oluşturan kemiklerin özellikle kafatası, gövde, üst uzuvlar, anatomik duruşları bozulmuş ve yer değiştirmiştir. Kafatası kemiği tümüyle yerinden oynamış, omurga aksı dağılmıs, kaburgalar ve kol kemikleri yerinden oynamıştır. Bununla birlikte alt uzuvlar (kalça-femur-patella, tibia, fibula ve ayak kemikleri) anatomik yerlerinde ve duruşlarını korumakta ve anatomik bağlantıları büyük oranda devam etmektedir. Kemiklerin yer değiştirmesi sonucunda oluşan "karışıklık", bütünüyle boş bir ortamda iskeletleşme ve devamında kemiklerin, süreç içerisinde küpün içine sızan toprağın itmesi, yer çekiminin etkisi, küpün iç bükey yapısı ve pürüzsüz bir yüzeyi olmasından kaynaklanmaktadır. SK 26 nolu gömüt, kemiklerdeki yer değisstirmeler nedeniyle görüntü olarak "ikincil gömüt" izlenimi oluşturmakla birlikte, arkeotanatolojik yöntemle değerlendirildiğinde tekli birincil gömüt olduğu tespit

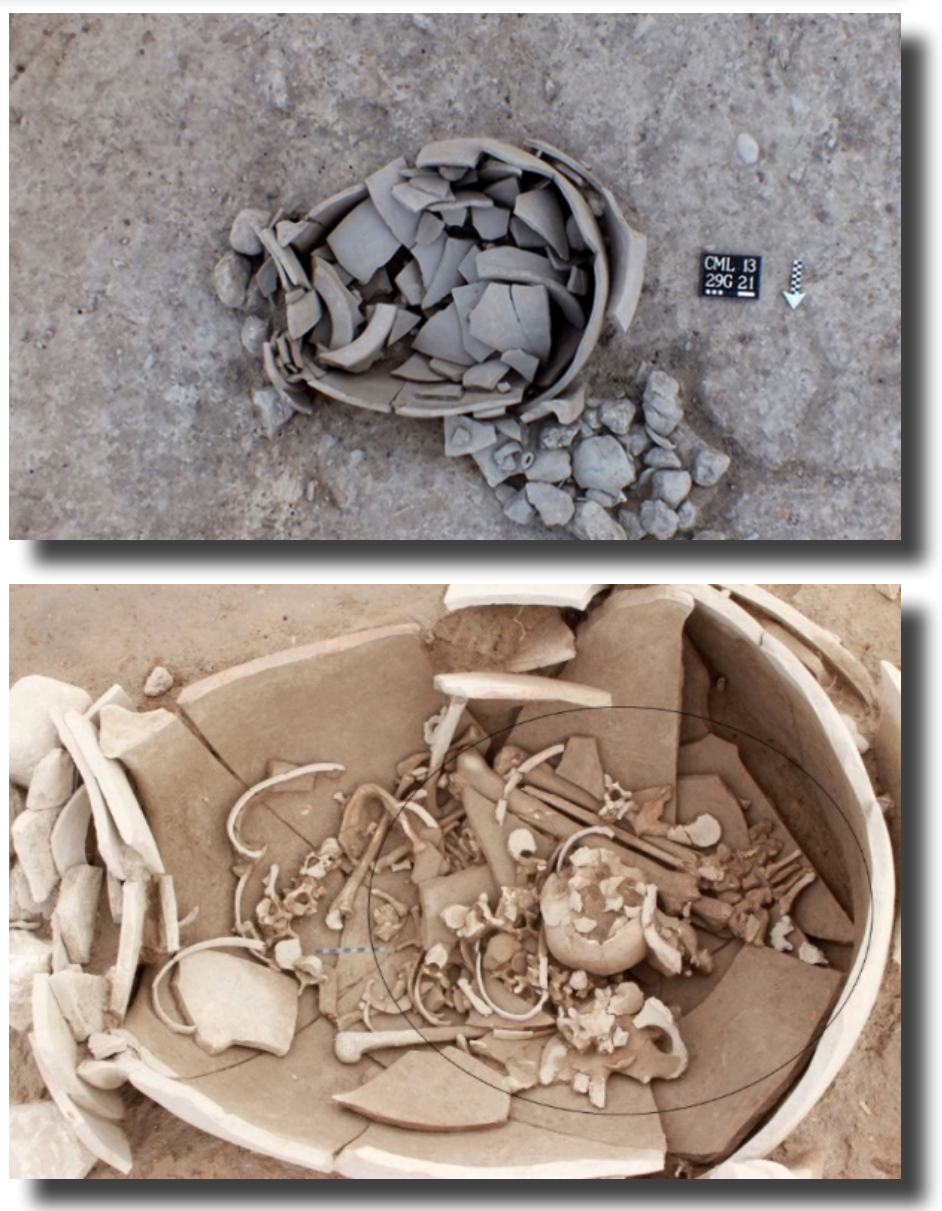

Resim 6. Cemialo Sırtı SK 26 nolu gömüt. Üstte kapalı, altta açılmıs küp ve daire içerisinde karışms kemikler görülebilir

(Fotoğraf: S. Gündüzalp | Cemialo kazı arșivi)

edilebilmektedir. Mickleburgha ve Wescott'in (2018) deneysel çalışması, boş bir ortamda cesedin iskeletleşmesi ve eklemlenmelerin sonlanmasiyla kemiklerdeki yer değiştirmelerin boyutunu göstermektedir. Çemialo SK 26 nolu gömütte saptanan özellikle bedenin üst kısmının yoğun olarak yer değiştirmesine karşın özellikle, gömüt tabanina veya bir sinıra yaslanan alt uzuvların anatomik duruşlarını koruması açısından benzer etkilerle benzer sonuçlar ortaya çıktığını göstermektedir. Ve bu gömüt için ileri sürdüğümüz boş bir ortamda iskeletleşen birincil gömüt hipotezini desteklemektedir.

\section{Tartışma}

Anadolu Arkeolojisi'nde gömüt uygulamaları, dönemlere göre farklılıklar gösteren zengin bir çeşitlilik sunmaktadır. Makalede Anadolu Arkeolojisi'nin farklı ölü gömme uygulamalarından örnekler verilmiş, bunlar arkeotanatolojik yöntemle kazılmış ve değerlendirilmiştir.

Pendik Höyük 42 nolu mezar (Resim 1), etrafi dolu bir ortamda iskeletleşmiş bir bireye aittir. Buna karşın kafatasının anatomik duruşu bozulmuş ve yer değiştirmiştir. $\mathrm{Bu}$ farklılaşmanın kafatası ve boyun omurları arasındaki dayanıksız eklemlenmelerin sonlanması, kafatasının duruş biçimi, gömüt ortamındaki 
ikincil boşluklar ve toprak dolgunun itici etkisi ile "doğal" bir süreçte yer değiştirdiği hipotezi ortaya konmuştur. Bu örnek, gömüt içerisindeki kemiklerin yer değiştirmesinin, insanlar tarafindan yapılma olasılı̆̆ kadar, gömütün içerisindeki doğal değişim süreçlerinden de kaynaklanabileceğini göstermesi açısından önemlidir.

Pendik Höyük 41 nolu mezar (Resim 2), cesede göre dar bir çukurun içerisine gömülmüş, iskeletleșmesi ve eklemlenmelerinin sonlanması etrafi dolu bir ortamda gerçekleşmiştir. Özellikle gömüt çukuru, kemikler üzerinde sınır etkisi yapmış ve buna göre duruş biçimleri şekillenmiştir. Gömüt çukuru tespit edilmeyen kazılarda, iskeletin duruş biçimi, özellikle de el, ayak ve kafatası uç kısımlardaki kemiklerin sınırı, çukurun sınırının belirlenmesine ve gömüt ortamının yeniden oluşturulmasını mümkün kılmaktadır. 41 nolu mezar, bu açıdan ilerde yapılacak çalışmalar için referans niteliği taşımaktadır.

Aşıklı Höyük SK 109 nolu birey, ölünün bir nesneye sarıldıktan sonra gömülmesi ve bu durumun iskeletleșme sürecine etkilerinin değerlendirilmesi açısından az bulunan kalıntılardandır. Ayrıca, özellikle mekân içi, taban altı gömütlerinde cesedin "etrafı boș bir ortamda mi yoksa dolu bir ortamda mı" iskeletleştiğinin saptanması için yapılacak tafonomik analizler, ölüler gömüldükten sonra, mekânın kullanım biçiminin belirlenmesine katk1 sunacaktır.

Yenikap1 Gömüt 3, SK 7, arkeolojik alanlarda çok nadir korunan ahşabın, cesedin iskeletleşme sürecinde doğrudan etkilerini belirlediğimiz önemli bir örnektir. Farklı gömütlerde ahşabın, başlangıçta mezar mimarisinde kullanılmış olabileceği ancak süreç içerisinde yok olduğu şüphesi oluştuğunda, SK 7'nolu iskeletin duruş biçimi, yerinden oynayan kemiklerin yönü vb. gibi değerlendirmelerle için referans olarak kullanılabilir. Bu iskeletle birlikte açı̆̆a çıkarılan kabın içerisinin dolu olarak ölüyle birlikte gömülmüş olması ve içerisindeki botanik kalıntılar, ölü nesnesi olarak çanak-çömleğin bulunduğu gömütlerde, kap içlerinin ve gömütün dolgusunun tümünün mutlaka flotasyon işleminden geçirilmesi gerektiğini göstermektedir.

Çemialo Sırtı SK 26 nolu gömüt boș bir alanda cesedin iskeletleşmesi ve eklemlenmelerin sonlanmasıyla, kemiklerin farklı etkenlerle yer değiştirme boyutunu gösteren önemli bir örnektir. Özellikle gömüt mimarisi ve gömüt ortamının (etrafi dolu veya boş) cesedin iskeletleşmesi üzerindeki etkileri değerlendirilmeden, gömütlerin kategorilerinin (birincil, ikincil) belirlenemeyeceğini göstermektedir. Mickleburgha ve Wescott'in (2018) deneysel çalışması ve SK 26 nolu bireyin kemiklerinin yer değiştirme durumu arasında paralellikler söz konusudur. Her ikisinde de kafatası ve bedenin üst bölümünü oluşturan kemikler daha çok yer değiştirmiştir. Alt uzuvlarda ise yer değiştirmeler daha azdır. Çemialo Sırtı Yerleșmesi'nde etrafı boș alanda iskeletleşen farklı gömütler kazılmıştır. Analizler tamamlandığında, farklı gömüt ortamlarının (etrafi boş, etrafı dolu ve ikincil boşluklar) cesedin iskeletleşmesi üzerindeki etkileri hakkında önemli bir referans serisi oluşturulabilecektir.

\section{Sonuç}

Anadolu Arkeolojisi'nde gömütler üzerine yapılan çalışmalar son yıllarda artmış ve detaylanmıştır. Bununla birlikte arkeotanatolojik perspektifle değerlendirildiğinde, birkaç önemli noktanın değişmesi ve geliştirilmesi gerekmektedir. Bunlardan ilki, arkeolojik kazılarda gömütlerin ağırlıklı olarak, hâlâ, insan osteolojisi bilmeyenler (arkeolog, arkeoloji öğrencisi) tarafindan kazısının yapılması ve bu durumun veri kaybına neden olmasıdır. Bir diğer önemli nokta ise gömüt kazılarının çoğunlukla, iskeletin etrafındaki topraktan "ayriştırılması" olarak ele alınması, özellikle toprağa açılan çukurlara ölünün gömüldüğü uygulamalarda, çukur sınırlarının gömütün mimarisini oluşturduğu, ölünün bunun içine gömüldüğü ve kazının çukurun sınırlarını koruyarak kazılması gerektiğinin nadiren dikkate alınmasıdır. Bu durum, gömütlerden bütünsel olarak alınabilecek veriyi yok etmektedir. Üçüncü önemli nokta, gömütlerin değerlendirilmesinde tafonomik analizlerin yaygin olarak kullanılmaması ve bunun sonucu olarak ölü gömme uygulamaları ile cesedin iskeletleşmesi ve eklemlenmelerin sonlanmasındaki doğal olguların arkeolojik verilerle ayrıştırılmamasıdır. $\mathrm{Bu}$ durum ölü gömme uygulamalarının net verilerle yeniden kurulmasını zorlaştırmaktadır. Arkeotanatolojik yöntemle yaptığımız çalışmalar, cesetlerin tafonomik sürecinden ve arkeolojik bağlamalarından derlenen verilerin sonuçları ile eski toplumun ölü gömme uygulamalarına dair hipotezler üretilebileceğini göstermektedir. Aynı zamanda, Anadolu Arkeolojisi'nde ölü gömme uygulamalarındaki zengin çeșitlilik arkeotanatolojik yöntemin geliştirilmesine önemli katkılar sunma potansiyeli taşımaktadır.

\section{Teşekkür}

Arkeotanatolojik yöntemin uygulamaları konusunda desteklerini sunan, İstanbul Arkeoloji Müzeleri emekli müdürü Zeynep Kızıltan'a, müdür Rahmi Asal'a, Mehmet Ali Polat'a, Sırrı Çölmekçi'ye, Prof. Dr. Ufuk Esin'e, Prof. Dr. Nur Balkan Atli'ya, Prof. Dr. Mehmet Özdoğan'a, Prof. Dr. Aslı Erim Özdoğan'a, Prof. Dr. Mihriban Özbaşaran'a, Prof. Dr. Françoise Le Mort'a, Prof. Dr. Henri Duday'e, Prof. Dr. Catherine Marro'ya, Aksel Tibet'e, Dr. Sidar Gündüzalp'e, Nisan Lordoğlu'na, Sinan Yiğit'e, Olgaç Oral'a, Evren Yıldız'a, Koray Akıncı'ya, Halil Yalçındağ’a, Filiz Yalçındağ’a ve Neris Nur Yılmaz'a teşekkürlerimi sunuyorum. 


\section{Kaynakça}

Alemdar, Z., ve Cavlak, M. (2019). Tibbi açıdan ölüm. A. M. Büyükkarakaya ve E. B. Aksoy (Ed.) içinde, Memento mori: Ölüm ve ölüm uygulamalar (s. 603-614). Ege Yayınları.

Andrews, P. (1997). What taphonomy can and cannot tell us. Cuadernos de Geologia Ibérica, (23), 53-72.

Arslan, M. N., ve Koç, S. (2016). Ölüm belirtileri. Türkiye Klinikleri, 2(1), 12-19.

Barnard, A. (2012). Simgesel düs̆̈ncenin doğuşu. Boğaziçi Üniversitesi Yayinlari.

Bocquentin, F., Chambon, P., Le Goff, I., Leclerc, J., Pariat J.G., Pereira, G., Thevenet, C. ve Valentin, F. (2010). De la récurrence à la norme: interpréter les pratiques funéraires en préhistoire. Bulletins et Mémoires de la Société d'Anthropologie de Paris, (22), 157-171. https://doi.org/10.1007/s13219-010$\underline{0017-8}$

Boulestin B. ve Duday, H. (2005). Ethnologie et archéologie de la mort: De l'illusion des références a l'emploi d'un vocabulaire', Mordan, C ve Depierre, G. (Ed.) Les Pratiques Funéraires a l'Age du Bronze en France. CTHS: 17-35.

Brůžek, J., Santos, F., Dutailly, B., Murail, P., ve Cunha, E. (2017). Validation and reliability of the sex estimation of the human os coxae using freely available DSP2 software for bioarchaeology and forensic anthropology. American Journal of Physical Anthropology, 164(2), 440-449. https://doi. org/10.1002/ajpa.23282

Büyükkarakaya, A. M. (2019) Ölüm uygulamaları ve davranışın ekolojisi. A. M. Büyükkarakaya ve E. B. Aksoy (Ed.) içinde, Memento mori: Ölüm ve ölüm uygulamalar (s. 217-245). Ege Yayınları.

Courtaud, P. (1996). "Anthropologie de sauvetage": Vers une optimisation des méthodes d'enregistrement présentation d'une fiche anthropologique. Bulletins et Mémoires de la Société d'Anthropologie de Paris, 8(3-4), 157-167.

Crubezy, E., (2000). L'etude des sépultures ou du monde des morts au monde des vivants, anthrobiologie, archéologie funéraire et anthropologie de terrain. E. Crubézy, E. Lorans, C. Masset, F. Perrin ve L. Tranoy (Ed.) içinde, L'Archéologie Funéraire (s. 8-54). Errance.

Crubezy, E., Duday, H., ve Janin, T. (1992). L'anthropologie de terrain: le particularisme Egyptien. Archéo-Nil, (2), 21-36.

Çimen, A. (1994). Anatomi. Uludağ Üniversitesi Basımevi.

Duday, H. (1978). Archéologie funéraire et anthropologie. application des relevés et de l'etude ostéologiques à l'interprétation de quelques sépultures pré et protohistoriques du midi de la France. Cahiers d'Anthropologie, (1), 55-101.

Duday, H. (1981). La place de l'anthropologie dans l'étude des sépultures anciennes. Cabiers d'Antbropologie, (1), 27-42.

Duday, H. (1990). Observations ostéologiques et décomposition du cadavre: sépultures colmatées ou en espace vide. Revue Archéologique du Centre de la France, 29(2), 193-196.

Duday, H. (1995). Anthropologie “de terrain”, archéologie de la mort. La mort, passé, présent, conditionnel. R. Joussaume (Ed.) içinde, Colloque du Groupe Vendéen d'Études Préhistoriques (La Roche-sur-Yon) (s. 33-58). La Rouche sur Yon: Groupe Vendéen d'Études Préhistoriques.
Duday, H. (1997). Mais, au fait, quelle anthropologie? Les Nouvelles de l'Archéologie, (66), 54-56.

Duday, H. (2005). L'archeothanatologie ou l'archéologie de la mort. O. Dutour, J. J. Hublin ve B. Vandermeersch (Ed.) içinde, Objets et Méthode en Paléoanthropologie (s. 153-215). CTHS.

Duday, H., (2011). The archaeology of the dead. Lectures in Archaeothanatology. Oxbov Books.

Duday, H., ve Masset C. (1987). Anthropologie physique et archéologie: méthodes d'étude des sépultures. CNRS Editions.

Duday, H., ve Sellier, P. (1990). L'archéologie des gestes funéraires et la taphonomie. Les Nouvelles de l'Archéologie, (40),12-14.

Duday, H. ve Guillon, M. (2006). Understanding the circumstances of decomposition when the body is skeletonized. A. Schmitt, E. Cunha ve J. Pinheiro (Ed.) içinde, Forensic anthropology and medicine. Complementary sciences from recovery to cause of death (s. 117-157). Humana Press. https://doi.org/10.1007/978-159745-099-7 6

Duday, H., Courtaud, P., Crubezy, E., Sellier, P., ve Tillier, A. M. (1990). L'anthropologie "de terrain": reconnaissance et interprétation des gestes funéraires. Bulletins et Mémoires de la Société d'Anthropologie de Paris, 2(3-4), 29-49. https://doi. org/10.3406/bmsap.1990.1740

Duday, H., Le Mort, F., ve Tillier, A. M. (2014). Archaeothanatology and funeral archaeology. Application to the study of primary single burials. Anthropologie, 52(3), 235-246.

Efremov, J.A. (1940). Taphonomy: New branch of paleontology. Pan-American Geologist, 74(2), 81-93.

Erim Özdoğan, A., ve Gündüzalp, S. (2018). Çemialo Sırtı Batman - Beşiri-Yazıhan Köyü. F. Baş (Ed.) içinde, Batman Müzesi Ilısu Barajı Kurtarma Kazılar (s. 201-209). Batman Müzesi Müdürlüğü Yayınları.

Esin, U. (1998). The aceramic site of Aş1klı and its ecological conditions based on its floral and faunal remains. TÜB $A-A R$, (1), 95-103. https://doi.org/10.22520/tubaar.1998.0006

Fabre, V. (1996). Fouille, enregistrement et analyse des Inhumations domestiques d'enfants. Bulletins et Mémoires de la Société d'Anthropologie de Paris, 8(3-4), 195-206. https://doi. org/10.3406/bmsap.1996.2442

Fabre V., Mariethoz, F, ve Steiner, L. (1987). Archéologie funéraire et anthropologie: experiences recentes en Suisse Occidentale. Bulletin Sociéte Suisse d'Anthropologie, 3(2),29-65.

Gallay, A., ve Chaix, L. (1984). Le site prehistorique du PetitChasseur. Cabiers d'Archeologie Romande, (32).

Grévin, G. (2004). L'ethnologie au secours des archéologues: L'etude des crémations sur bûchers. Archéologia, (408), 44-51.

Henry-Gambier, D. (2008). Comportement des populations d'Europe au Gravettien: Pratiques funeraires et interpretations. Paleo, (20), 165-204. https://doi.org/10.4000/paleo.1632

Houck, M. M., ve Siegel, J.A. (2016). Adli bilimlerin temeli. Y. Doğan (Çev. Ed.). Nobel Yayınevi.

Knüsel, C. J. (2014). Crouching in fear: terms of engagement for funerary remains. Journal of Social Archaeology, 14(1), 26-58. https://doi.org/10.1177/1469605313518869

Knüsel,C. J., ve Robb, J. (2016). Funerary taphonomy: An overview of goals and methods. Journal of Archaeological Science, 10. 655- 
673. https://doi.org/10.1016/i.jasrep.2016.05.031

Kızıltan, Z. (2015a) Pendik höyük kazıları. C. Yılmaz (Ed.) içinde, Antik Căg'dan XXI. yüzynla büyük Istanbul taribi (s. 369-371). İBB Yayınları.

Kızıltan, Z. (2015b) İstanbul kazıları, Marmaray-metro projeleri ve arkeolojik kurtarma kazılarının şehir tarihine katkıları. C. Yllmaz (Ed.) içinde, Antik Cağgdan XXI. yürynla büyük Istanbul Taribi (s. 338-373). İBB Yayınlar1.

Kızıltan, Z., ve Polat, M. A. (2013). Yenikap1 kurtarma kazıları: Neolitik Dönem çalışmaları. Arkeoloji ve Sanat Dergisi, (143), $1-40$.

Koç, S., ve Can, M. (2009). Ölüm kavramı ve ölü muayenesi. Klinik Gelişim Dergisi, 22, 11-22.

Le Mort, F. (1990). La decoupe du cadavre. Les Nonvelles de l'Archeologie, (40), 25-26.

Le Mort, F., Erim-Özdoğan, A., Özbek, M., ve Y1lmaz, Y. (2000). Feu et archéoanthropologie au Proche-Orient (épipaléolithique et néolithique). Le lien avec les pratiques funéraires. Données nouvelles de Çayönü (Turquie). Paléorient, 26(2), 37-50. https://doi.org/10.3406/paleo.2000.4708

Leclerc, J., ve Tarrete, J. (1997). Sépulture. A. Leroi-Gourhan (Ed.) içinde, Dictionnaire de la Prébistoire (s. 1002-1003). Quadrige.

Leroi-Gourhan, A. (1964). Les religions de la Prébistoire. Quadrige/ Presse Universitaires de France.

Leroi-Gourhan, A., Bailloud, G., ve Brezillion, M. (1962). L’hypogée II des Mournouards (Mesnil-sur-Oger, Marne). Gallia Prébistoire, 5(1), 23-133. https://doi.org/10.3406/ galip.1962.1203

Lyman, R. L.(1987). Zooarchaeology and taphonomy: A general consideration. Journal of Ethnobiology, 7(1), 93-117.

Mickleburgha, H. L., ve Wescott, D. J. (2018). Controlled experimental observations on joint disarticulation and bone displacement of a human body in an open pit: Implications for funerary archaeology. Journal of Archaeological Science: Reports, 20. 158-167. https://doi.org/10.1016/j.jasrep.2018.04.022

Peressinotto, M. D. (2007). Chronologie de la dislocation articulaire du squelette axial et des ceinttures au cours de la decomposition du cadavre apports a l'analyse des sépultures [Yayımlanmamış doktora tezi]. École doctorale Sciences du Vivant, Géosciences et Sciences de l'Environnement, l'Université Bordeux 1.

Rogers, C. J. (2010). Dating death: Forensic taphonomy and the postmortem interval [Yayımlanmamış doktora tezi]. University of Wolverhampton, School of Applied Science.

Sprague, R. (2005). Burial terminology: A guide for researchers. Alta Mira Press.

Süzen, L. B. (2013). Insan anatomisine giriş. Nobel Tip Kitabevleri.

Thomas L.V. (1978). Mort et Powvoir. Payot.

Tillier, A. M. (1990). Une controverse dépassée: L'existence de pratiques funéraires au paléolithique moyen. Les Nouvelles de l'Archéologie, (40). 22-24.

Tillier, A. M. (2009). L'bomme et la mort. CNRS Editions.

Yaka, R., Birand, A., Yılmaz,Y., Caner, C., Açan, S. C., Gündüzalp, S., Parvizi, P., Erim Özdoğan, A., Togan, İ., ve Somel, M. (2018). Archaeogenetics of late Iron Age Çemialo Sırt1,
Batman: Investigating maternal genetic continuity in north Mesopotamia since the Neolithic. American Journal of Physical Anthropology, 166(1), 196-207. https://doi.org/10.1002/ ajpa. 23423

Yılmaz, Y. (2002). Aşıklı Höyük iskeletlerinin morfolojik olarak karşılaştırmal incelenmesi [Yayımlanmamış yüksek lisans tezi]. İstanbul Üniversitesi, Sosyal Bilimler Enstitüsü.

Y1lmaz, Y. (2010) Neolitik Dönem'de Anadolu'da ölü gömme uygulamalar: Cayönü örneği [Yayımlanmamış doktora tezi]. İstanbul Üniversitesi, Sosyal Bilimler Enstitüsü.

Y1lmaz, Y. (2011). Marmara Bölgesi Neolitik Dönem ölü gömme geleneklerinde ilkler: Yenikapı kazı bulguları. TÜBA-AR, (14), 283-302. https://doi.org/10.22520/tubaar.2011.0022

Yılmaz, Y. (2014). Bir yerleşim, bir yöntem: Yenikapı Neolitik Dönem gömütlerinin kazılması, belgelenmesi ve değerlendirilmesi. Ş. Baltaş ve Ş. Altun (Ed.) içinde, Hayalden gerçeğe bir İstanbul öyküsü Marmaray (s. 256-270). Gama Holding.

Yılmaz, Y. (2019). Araziden analize gömütler: Sinıflandırma, adlandırma ve inceleme dinamikleri. P. Çaylı, I. Demirtaş ve B. Eser (Ed.) içinde, Arkeolojiyle gẹen yarm asir: Sevil Gülçur Armağanı (s. 619-646). Bilgin Kültür Sanat Yayınları.

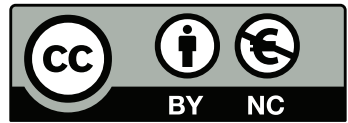

2021. Telif haklar1 yazar(lar)a aittir.

Bu makale Creative Commons Atıf-GayriTicari 4.0 Uluslararası (CC BY-NC 4.0) lisansının hüküm ve şartları altında yayımlanan açık erişimli bir makaledir. 